University of Nebraska - Lincoln

DigitalCommons@University of Nebraska - Lincoln

U.S. Environmental Protection Agency Papers

U.S. Environmental Protection Agency

$12-19-2018$

\title{
Seasonality of nitrogen balances in a Mediterranean climate watershed, Oregon, US
}

Jiajia Lin

National Research Council, National Academy of Sciences \& Western Ecology Division, jlin42@outlook.com

Jana E. Compton

Western Ecology Division, compton.jana@epa.gov

Scott G. Leibowitz

Western Ecology Division, leibowitz.scott@epa.gov

George Mueller-Warrant

USDA ARS, National Forage Seed Production Research Center, george.mueller-warrant@usda.ars.gov

William Matthews

Oregon Department of Agriculture, Confined Animal Feeding Operations, wmatthews@oda.state.or.us

See next page for additional authors

Follow this and additional works at: https://digitalcommons.unl.edu/usepapapers

Part of the Earth Sciences Commons, Environmental Health and Protection Commons, Environmental Monitoring Commons, and the Other Environmental Sciences Commons

Lin, Jiajia; Compton, Jana E.; Leibowitz, Scott G.; Mueller-Warrant, George; Matthews, William; Schoenholtz, Stephen H.; Evans, Daniel M.; and Coulombe, Rob A., "Seasonality of nitrogen balances in a Mediterranean climate watershed, Oregon, US" (2018). U.S. Environmental Protection Agency Papers. 288.

https://digitalcommons.unl.edu/usepapapers/288

This Article is brought to you for free and open access by the U.S. Environmental Protection Agency at DigitalCommons@University of Nebraska - Lincoln. It has been accepted for inclusion in U.S. Environmental Protection Agency Papers by an authorized administrator of DigitalCommons@University of Nebraska - Lincoln. 


\section{Authors}

Jiajia Lin, Jana E. Compton, Scott G. Leibowitz, George Mueller-Warrant, William Matthews, Stephen H. Schoenholtz, Daniel M. Evans, and Rob A. Coulombe 


\title{
Seasonality of nitrogen balances in a Mediterranean climate watershed, Oregon, US
}

\author{
Jiajia Lin (1) - Jana E. Compton • Scott G. Leibowitz • George Mueller-Warrant • \\ William Matthews • Stephen H. Schoenholtz - Daniel M. Evans • \\ Rob A. Coulombe
}

Received: 31 May 2018/Accepted: 4 December 2018/Published online: 19 December 2018

(C) This is a U.S. government work and not under copyright protection in the U.S.; foreign copyright protection may apply 2018

\begin{abstract}
We constructed a seasonal nitrogen (N) budget for the year 2008 in the Calapooia River Watershed (CRW), an agriculturally dominated tributary of the Willamette River (Oregon, U.S.) under Mediterranean climate. Synthetic fertilizer application to agricultural land (dominated by grass seed crops) was the source of $90 \%$ of total $\mathrm{N}$ input to the CRW. Over $70 \%$ of the stream $\mathrm{N}$ export occurred during the wet winter, the primary time of fertilization and precipitation, and the lowest export occurred in the dry summer. Averaging across all 58 tributary subwatersheds, $19 \%$ of annual $\mathrm{N}$ inputs were exported by streams, and $41 \%$ by crop harvest. Regression analysis
\end{abstract}

Responsible Editor: Jack Brookshire.

Electronic supplementary material The online version of this article (https://doi.org/10.1007/s10533-018-0532-0) contains supplementary material, which is available to authorized users.

\section{J. Lin $(\square)$}

National Research Council, National Academy of Sciences, 200 SW 35th St, Corvallis, OR 97333, USA

e-mail: jlin42@outlook.com

J. Lin · J. E. Compton · S. G. Leibowitz

Western Ecology Division, US EPA, 200 SW 35th St, Corvallis, OR 97333, USA

J. E. Compton

e-mail: compton.jana@epa.gov

S. G. Leibowitz

e-mail: leibowitz.scott@epa.gov of seasonal stream export showed that winter fertilization was associated with $60 \%$ of the spatial variation in winter stream export, and this fertilizer continued to affect $\mathrm{N}$ export in later seasons. Annual $\mathrm{N}$ inputs were highly correlated with crop harvest $\mathrm{N}$ $\left(\mathrm{r}^{2}=0.98\right)$, however, seasonal dynamics in $\mathrm{N}$ inputs and losses produced relatively low overall nitrogen use efficiency $(41 \%)$, suggesting that hydrologic factors may constrain improvements in nutrient management. The peak stream $\mathrm{N}$ export during fall and early winter creates challenges to reducing $\mathrm{N}$ losses to groundwater and surface waters. Construction of a seasonal $\mathrm{N}$ budget illustrated that the period of greatest $\mathrm{N}$ loss is disconnected from the period of greatest crop $\mathrm{N}$ uptake. Management practices that serve to reduce the $\mathrm{N}$ remaining in the system at the end of the growing season and prior to the fall and winter rains should be explored to reduce stream $\mathrm{N}$ export.

G. Mueller-Warrant

USDA ARS, National Forage Seed Production Research

Center, 3450 SW Campus Way, Corvallis, OR 97331,

USA

e-mail: george.mueller-warrant@usda.ars.gov

W. Matthews

Oregon Department of Agriculture, Confined Animal

Feeding Operations, 635 Capitol St NE, Salem, OR, USA

e-mail:wmatthews@oda.state.or.us 
Keywords Agriculture · GIS · Nutrient use efficiency · Grass seed crops · Seasonal analysis . Water quality $\cdot$ Nitrogen

\section{Introduction}

Production of food and energy required by rising human populations has released large amounts of nitrogen $(\mathrm{N})$ to the environment over the past century (Galloway et al. 2004). All forms of $\mathrm{N}$ other than $\mathrm{N}_{2}$ gas are defined as reactive $\mathrm{N}$, which is produced naturally by biological $\mathrm{N}$-fixation and lightning and by human activities, including cultivation of $\mathrm{N}$-fixing crops, fossil fuel combustion, and production of fertilizers and munitions (Davidson et al. 2011). Although the production and use of reactive $\mathrm{N}$ supports human nutrition and well-being for a growing global population, release of excess $\mathrm{N}$ beyond its intended use has contributed to the degradation of air quality, contamination of drinking water, hypoxia in coastal waters, and emission of greenhouse gases to the atmosphere (Sobota et al. 2015; Pennino et al. 2017; van Grinsven et al. 2013). While $\mathrm{N}$ release is a global problem, much of the $\mathrm{N}$ released to the environment occurs via local, non-point source pathways (Sobota et al. 2013). Developing the best available information on $\mathrm{N}$ sources and loads in a timely manner at the subwatershed scale is needed to promote local, effective management of nitrogen (Stoner 2011).

Budgets have been developed at different scales to quantify reactive $\mathrm{N}$ sources and to examine drivers of $\mathrm{N}$ release to the environment. Howarth et al. (1996) estimated the total $\mathrm{N}$ flux to the North Atlantic Ocean

S. H. Schoenholtz

Virginia Water Resources Research Center, Cheatham Hall, Suite 210, Virginia Tech, 310 West Campus Drive, Blacksburg, VA 24061, USA

e-mail: stephen.schoenholtz@vt.edu

D. M. Evans

Center for the Environment, Plymouth State University, Plymouth, NH 03264, USA

e-mail: dmevans1@mail.plymouth.edu

R. A. Coulombe

CSS, 200 SW 35th St, Corvallis, OR 97333, USA

e-mail: coulombe.rob@epa.gov from 14 regions, and identified northeastern U.S. and northwestern Europe watersheds as contributing the largest $\mathrm{N}$ fluxes on a per unit area basis. They identified sources of $\mathrm{N}$ within watersheds with high human population density and a variety of land uses. Many studies have examined annual $\mathrm{N}$ inputs and outputs at regional scales and how they are affected by human activities and watershed characteristics, for example in the Illinois River Basin (David and Gentry 2000), the Sacramento-San Joaquin Valley of California (Sobota et al. 2009), and the eastern US (Boyer et al. 2002; Schaefer and Alber 2007). Goolsby et al. (1999) assembled a comprehensive $\mathrm{N}$ budget for the Mississippi River Basin that also included estimates for $\mathrm{N}$ mineralization, immobilization, and denitrification in soil, and $\mathrm{N}$ volatilization from crop canopies. Annual $\mathrm{N}$ loss via stream flux has been shown to be a function of net anthropogenic input (David and Gentry 2000; Howarth et al. 2012; McIsaac et al. 2002), annual stream flow (Schaefer et al. 2009; Sobota et al. 2009), and changes in land use or nutrient management (Hirsch et al. 2010). These studies establish the foundations for predicting $\mathrm{N}$ loss on an annual basis and for a range of anthropogenic sources.

Although large-scale, annual budgets are useful for identifying drivers of inputs to regions or large coastal areas like the Gulf of Mexico or the North Atlantic, studies that incorporate data about local land use and finer time steps are vital for informing local water quality management. Studies comparing models demonstrated that $\mathrm{N}$ budgets incorporating more detail on $\mathrm{N}$ sources and land/water attenuation substantially improve predictions of $\mathrm{N}$ export both at catchment scales (Han and Allan 2008) and larger scales (Alexander et al. 2002). High-resolution, locally derived information on nutrient inputs to the landscape from different sources can identify opportunities for reducing $\mathrm{N}$ loading to sensitive surface waters and groundwater systems (Luscz et al. 2015).

Many regional or smaller scale studies have been carried out to understand watershed $\mathrm{N}$ balances in the Midwestern, Southern, and Eastern US (Boyer et al. 2002; David et al. 1997; Schaefer et al. 2009). Studies are needed to examine watershed $\mathrm{N}$ budgets in the Pacific Northwestern US (PNW), in order to enhance our knowledge of $\mathrm{N}$ management in the distinctive Mediterranean climate of the PNW with wet winters and dry summers. Hydrologic $\mathrm{N}$ export increases in months with high precipitation, and generally is higher 
in the wetter, west-side mountains of Oregon and Washington than in other parts of the western US (Kelley et al. 2013; Schaefer et al. 2009; Wise and Johnson 2011). A number of TMDLs (Total Maximum Daily Loads) have been developed in these states for impaired waters that target nutrients as contributing pollutants to violations of water quality standards (USEPA 2018). In agricultural areas of central and northwestern Washington and Oregon's Willamette Valley, groundwater nitrate concentrations often are above the drinking water maximum contaminant level of $10 \mathrm{mg} \mathrm{NO} \mathrm{NO} \mathrm{L}^{-1}$ (Hoppe et al. 2011; Nolan and Hitt 2006; Pennino et al. 2017). An examination of inputs and exports at finer temporal and spatial scales may improve our understanding of the drivers of these high yields and concentrations, and in turn inform water-quality management in regions with similar climate and N-related water-quality problems.

The Calapooia River is a major tributary of the Willamette River Basin in Oregon, previously identified as having high $\mathrm{N}$ concentrations relative to many other Willamette tributaries (Bonn et al. 1996). Here we apply the best available local and regional data to assemble a comprehensive, seasonal $\mathrm{N}$ input-output budget for the Calapooia River Watershed (CRW) in 2008. We chose 2008 because high resolution land cover and input data coincided with stream chemistry data for a network of 73 stream sampling locations in the CRW. Quantified N inputs include agricultural, industrial, human and animal waste, and natural sources; exports include crop harvest and hydrologic export. Objectives of the study were to (1) quantify contributions of various $\mathrm{N}$ sources in the $\mathrm{CRW}$ and its subwatersheds for the year 2008 using locally-derived, crop-specific land-use information; (2) estimate fractional $\mathrm{N}$ export via stream export and crop harvest; (3) quantify the amount of $\mathrm{N}$ remaining in the watershed; (4) study spatial and temporal variations in $\mathrm{N}$ inputs and exports, and (5) explore dominant factors that drive these variations. Previous work at the national scale has shown that the spatial patterns of $\mathrm{N}$ export are generally driven by inputs, but that climate factors like precipitation dominate the temporal variability in exports (Sinha and Michalak 2016). Our goal was to use a high-resolution dataset derived from local crop cover and fertilizer information to examine the relative importance of both $\mathrm{N}$ inputs and hydrology in affecting seasonal and annual $\mathrm{N}$ balances within the watershed.

\section{Methods}

Study area

The Calapooia River is a major tributary of the Willamette River, originating on the western slopes of the Cascade Mountains of Oregon. Approximately $43 \%$ of the Calapooia River Watershed (CRW) is occupied by evergreen forest (mostly short-rotation industrial timber), mainly in the mountainous upper watershed, and 53\% is occupied by agricultural land, predominantly grass seed crops in the flat valley floor (Mueller-Warrant et al. 2011) (Fig. 1). The Calapooia is a perennial stream with a mean discharge of $25 \mathrm{~m}^{3} \mathrm{~s}^{-1}$ and a watershed area of $963 \mathrm{~km}^{2}$ (Runyon et al. 2004). Watershed elevation ranges from 56 to $1576 \mathrm{~m}$. Precipitation occurs mostly from October to May (Runyon et al. 2004), ranging from $<1000 \mathrm{~mm} \mathrm{year}^{-1}$ at low elevations to $>2000 \mathrm{~mm} \mathrm{year}^{-1}$ in the foothills of the mountain range (Hoag et al. 2012). Soils are dominated by Amity (Xeric Argialbolls) and Dayton (Vertic Albaqualfs) silt loam soil series in the valley and a variety of Inceptisols in the mountainous areas (USDA 2017). Among the 73 studied subwatersheds of the CRW that represent the entire drainage upstream, 15 are mainstream subwatersheds, and 58 are un-nested tributary subwatersheds. The dominant land use of these tributaries shifts from evergreen forest in the mountainous area to cool-season grass seed crops on the flat land (Fig. 1).

\section{$\mathrm{N}$ input}

Our goal was to assemble a comprehensive inputoutput $\mathrm{N}$ budget for the CRW for 2008, the year that we were able to gather the finest resolution, locallyderived data on land use, $\mathrm{N}$ deposition, and CAFOs to combine with stream chemistry data from the same time period. 2008 is also a normal year with average temperature and precipitation in a 10-year record (2002-2012). Seven sources of $N$ were examined: (1) land application of agricultural fertilizer, (2) land application of manure from concentrated animal feeding operations (CAFOs), (3) atmospheric deposition, (4) biological $\mathrm{N}$ fixation (BNF) by crops, (5) BNF associated with red alder trees (Alnus rubra), (6) nonagricultural fertilizer applied to developed lands, and (7) non-sewered septic waste (Table 1). We calculated 
Fig. 1 The Calapooia River Watershed. Land use in 2008, modified based on USDA-ARS map (MuellerWarrant et al. 2011). The flat western lower portion of the watershed is dominated by agricultural land, and mountainous eastern portion by forestland

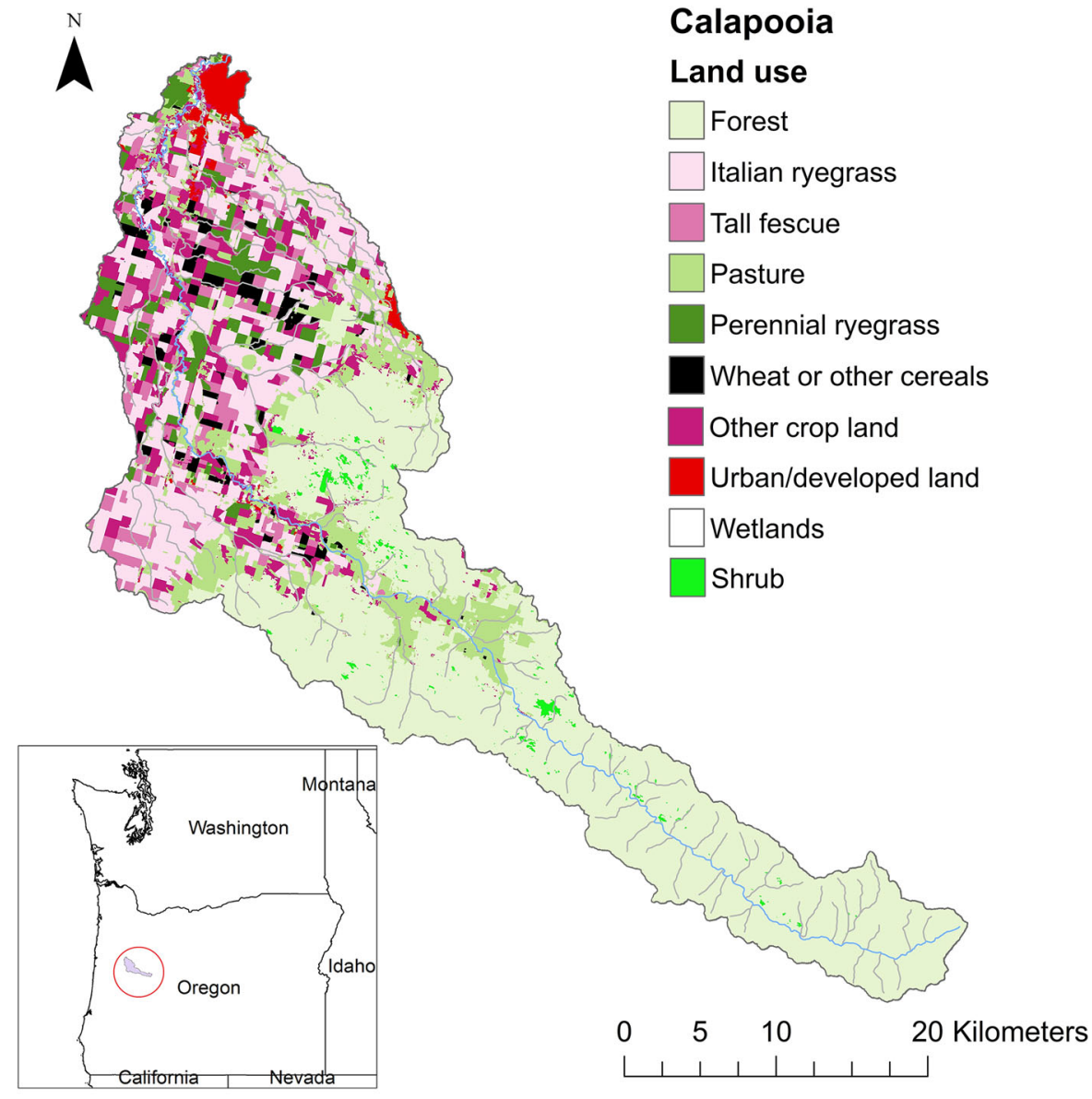

total $\mathrm{N}$ input from these seven sources at the watershed- and subwatershed levels (see SI for more information). The total annual $\mathrm{N}$ input rate $\left(\mathrm{kg} \mathrm{N} \mathrm{ha}^{-1}\right.$ year $\left.^{-1}\right)$ was calculated as the sum of all 7 inputs listed above scaled to the entire watershed or subwatershed area in hectares (ha).

$\mathrm{N}$ outputs

\section{Stream export}

The US Geological Survey (USGS) Load Estimator model (LOADEST; Runkel et al. 2004) was used to simulate stream N load from 2002 to 2012 based on stream chemistry data collected for 73 stream sampling points within the CRW. The calibrated model was then used to extract the $\mathrm{N}$ load results for the year 2008.

Surface water grab samples were collected and analyzed for total nitrogen (TN) concentrations from the 15 mainstream and 58 tributary stations in the CRW from 2003 to 2006 (monthly or quarterly) by the US Department of Agriculture (USDA) and Oregon State University (OSU), and from 2009 to 2011 (quarterly) by the US Environmental Protection Agency (EPA). The detection limit for the EPA samples was $0.010 \mathrm{mg} \mathrm{N} \mathrm{L}^{-1}$; the detection limit for the USDA-ARS method was $0.04 \mathrm{mg} \mathrm{N} \mathrm{L}^{-1}$ (Erway et al. 2005; Evans 2007). See SI for detailed methods for sample collection and analysis. A calibrated hybrid hydrologic model, based in part on EXP-HYDRO (Patil and Stieglitz 2014) and developed specifically for the CRW, provided daily runoff estimates (in $\mathrm{mm}$ ) for streams to convert TN concentrations to loads (see SI for more details).

The LOADEST simulation produced continuous TN load output at a daily step, which was then aggregated to calculate monthly, seasonal, and annual stream export of TN at the Calapooia River main stem and tributary sites. The simulation at each site was 
Table 1 Summary of watershed nitrogen inputs and data sources for the Calapooia River Watershed, Oregon USA

\begin{tabular}{|c|c|c|c|c|}
\hline N Source & $\begin{array}{l}\text { Input } \\
\left(\mathrm{kg} \mathrm{N} \mathrm{ha}^{-1} \text { year }^{-1}\right)\end{array}$ & $\begin{array}{l}\text { Percent of all } \\
\mathrm{N} \text { inputs }(\%)\end{array}$ & GIS data layer source and data year & Resolution \\
\hline $\begin{array}{l}\text { Agricultural } \\
\text { fertilizer }\end{array}$ & 80.0 & 90.0 & $\begin{array}{l}\text { USDA-ARS }^{\mathrm{a}} \text { (land use data, 2008); OSU extension } \\
\text { recommendations for crop fertilization rates (SI } \\
\text { Table 1) }\end{array}$ & $30 \mathrm{~m} \times 30 \mathrm{~m}$ \\
\hline $\begin{array}{l}\text { Total } \\
\text { Atmospheric } \\
\text { deposition }\end{array}$ & 4.9 & 5.4 & $\mathrm{CMAQ}^{\mathrm{b}}(2008)$ & $4 \mathrm{~km} \times 4 \mathrm{~km}$ \\
\hline $\begin{array}{l}\text { Agricultural } \\
\mathrm{BNF}^{\mathrm{c}}\end{array}$ & 2.3 & 2.5 & USDA-ARS $^{\mathrm{a}}$ (land use data, 2008) & $30 \mathrm{~m} \times 30 \mathrm{~m}$ \\
\hline Alder $\mathrm{BNF}^{\mathrm{c}}$ & $1.4^{\mathrm{d}}$ & 1.5 & LEMMA $^{\mathrm{e}}(2002)$ & $30 \mathrm{~m} \times 30 \mathrm{~m}$ \\
\hline $\begin{array}{l}\text { Non-farm } \\
\text { fertilizer }\end{array}$ & 0.2 & 0.2 & USGS-SPARROW $^{\mathrm{f}}(2002)$ & $30 \mathrm{~m} \times 30 \mathrm{~m}$ \\
\hline $\mathrm{CAFO}^{\mathrm{g}}$ manure & 0.2 & 0.2 & Oregon Department of Agriculture records (2008) & $30 \mathrm{~m} \times 30 \mathrm{~m}$ \\
\hline $\begin{array}{c}\text { Non-sewered } \\
\text { population }\end{array}$ & 0.1 & 0.1 & USGS-SPARROW $^{\mathrm{f}}(2002)$ & $30 \mathrm{~m} \times 30 \mathrm{~m}$ \\
\hline Total & 89.0 & 100.0 & & \\
\hline
\end{tabular}

${ }^{\text {a Agricultural Research Service }}$

${ }^{\mathrm{b}}$ Community Multiscale Air Quality Model (version 4.7.1) (Schwede and Lear 2014)

${ }^{\mathrm{c}}$ Biological Nitrogen Fixation

${ }^{\mathrm{d}}$ Red alder fixation rate: $100 \mathrm{~kg} \mathrm{~N} \mathrm{ha}^{-1}$ year $^{-1}$, pure stand (chose lower range of 100-200 from Binkley et al. 1994, thus this is a conservative estimate)

${ }^{\mathrm{e}}$ Landscape Ecology, Modeling, Mapping and Analysis (Ohmann et al. 2011)

${ }^{\mathrm{f}}$ Spatially Referenced Regressions on Watershed Attributes (Wise and Johnson 2013)

${ }^{\mathrm{g}}$ Confined Animal Feeding Operation derived manure applied to farmland

calibrated and evaluated using the Nash-Sutcliffe coefficient $\left(\mathrm{R}_{\mathrm{NS}}^{2}\right)$ and Load Bias in Percent $\left(\mathrm{B}_{\mathrm{P}}\right)$, a coefficient that describes percent over/under estimation of the observed load within the calibration data set (USGS 2013). The $\mathrm{R}_{\mathrm{NS}}^{2}$ averaged 0.77 for all sites. The calibrated absolute value of $B_{p}$ averaged $6.4 \%$ for all subwatersheds (see SI for details).

\section{Crop harvest $N$ removal}

To calculate the $\mathrm{N}$ removal via crop harvest, we combined information acquired from a crop $\mathrm{N}$ content literature review with the 2008 land use map created by USDA-ARS. The ARS land use map identified 30 types of major crops in the CRW. The total crop removal of $\mathrm{N}$ was calculated as:

$N_{\text {crop }, r m v}=\sum_{i=1}^{i} A_{i} \times Y_{i} \times\left(1-m_{i}\right) \times n_{i}$ where $N_{\text {crop,rmv }}$ is the total crop removal of $\mathrm{N}$ $\left(\mathrm{kg} \mathrm{N} \mathrm{ha}^{-1}\right.$ year $\left.^{-1}\right)$ of the watershed; $A_{i}$ and $Y_{i}$ are respectively the planting area (ha) and yield ( $\mathrm{kg} \mathrm{ha}^{-1}$ year $^{-1}$ ) of crop $i ; m_{i}$ is the moisture content (\%) of crop $i$, and $n_{i}$ is the $\mathrm{N}$ content (\%) of crop $i$ on a dry weight basis. Planting area was based on the ARS land use map. USDA National Agricultural Statistics Service census data of 2007 and 2012 at the county level were used to calculate crop yield for individual fields, assuming crop yield is relatively constant. Crop yield refers to the part of the crop removed from the field during harvest. For example, in the study area, most of the grass straw is baled and removed for export during seed harvest. Therefore, $\mathrm{N}$ content in seed and straw were calculated separately then added together to estimate total $\mathrm{N}$ removal of grass seed crops. OSU extension publications (see SI Table 1) and the online USDA Crop Nutrient Tool (https://plants.usda.gov/ $\mathrm{npk} / \mathrm{main}$ ) were used to obtain the median crop moisture and $\mathrm{N}$ content. 
Surplus and remainder $\mathrm{N}$

Surplus $\mathrm{N}\left(\mathrm{N}_{\text {sur }}\right)$ is determined as the annual difference between total $\mathrm{N}$ inputs and crop harvest removal of $\mathrm{N}$ (Zhang et al. 2015), and represents the annual $\mathrm{N}$ inputs minus crop harvest.

$N_{\text {sur }}=\sum N_{\text {in }}-N_{\text {harv }}$

where $\sum N_{\text {in }}$ is the sum of the $\mathrm{N}$ input rate from the seven major $\mathrm{N}$ sources in the watershed (Table 1) and $N_{\text {harv }}$ is crop removal (Eq. 1). All terms are expressed as $\mathrm{kg} \mathrm{N}^{-1}$ year $^{-1}$.

Remainder $\mathrm{N}$ was also estimated for the Calapooia and its subwatersheds. We define remainder $\mathrm{N}\left(N_{\text {remn }}\right)$ as the amount of annual $\mathrm{N}$ inputs remaining in the watershed after removal via crop harvest and hydrologic export. It is calculated by subtracting total $\mathrm{N}$ removal via harvest and stream export from the total input on a per area basis:

$N_{\text {remn }}=\sum N_{\text {in }}-N_{\text {harv }}-N_{\text {str }}$

where $N_{\text {str }}$ is LOADEST derived stream export in $\mathrm{kg} \mathrm{N}^{-1}$ year $^{-1}$. Possible fates of the remainder $\mathrm{N}$ within the watershed include storage in fields in plant perennial tissues or in soil, or elsewhere in the watershed, e.g., in riparian zones. Remainder $\mathrm{N}$ could also leach into groundwater or be lost from farm and riparian soils in gaseous forms via denitrification and/ or volatilization.

\section{Seasonal analyses}

Linear regression analysis was conducted to investigate factors associated with seasonal stream export of $\mathrm{N}$ from agricultural tributary subwatersheds. Total $\mathrm{N}$ input for each season, seasonal crop harvest removal of $\mathrm{N}$, and seasonal fertilizer input were used as initial explanatory variables. Seasonal crop harvest removal was calculated as the sum of all the crop harvest occurring during that season in CRW. Seasonal fertilizer input was the total amount of fertilizer applied to all crop types based on crop $\mathrm{N}$ demand and extension recommendations for that season; thus we were able to account for additional fall fertilization to some grass seed crops and split fertilization. This analysis allowed us to break down the annual budget into a finer scale and to characterize stream export of $\mathrm{N}$ in each season.
To examine potential inter-seasonal interactions, we added explanatory variables that represented net $\mathrm{N}$ input accumulated respectively from the current season alone, individual previous seasons, (NET Winter, $\left.N E T_{\text {Spring, }} N E T_{\text {Summer }}, N E T_{\text {Fall }}\right)$, and both current and previous seasons (NET $T_{\text {Winter+Spring, }} \quad N E T$ Winter+Spring+Summen $\quad$ NET Winter+Spring+Summer+Fall $)$. The 'net' seasonal terms allow us to study factors controlling seasonal variation in $\mathrm{N}$ export and calculate the legacy impact from preceding seasons. For example, $N E T_{\text {Winter+Spring+Summer }}$ is net $\mathrm{N}$ subject to stream export at the end of summer after spring and winter export and summer harvest. $\mathrm{N}$ removal via winter harvest was considered as zero in our analysis because there was no harvest between January and March in the CRW. Therefore, $N E T_{\text {Winter }}$ + Spring+Summer was calculated as: [Total input of $\mathrm{N}_{\text {Winter }}$ + Spring + Summer $]-\left[\right.$ Stream export Winter + Spring $\left._{1}\right]-[$ Crop removal $\left._{\text {Spring }+ \text { Summer }}\right]$.

\section{Results}

Sources and rates of $\mathrm{N}$ inputs

Spatial distributions of $\mathrm{N}$ input rates across the CRW, consisting of agricultural fertilizer, alder BNF, agricultural BNF, total deposition, and non-farm fertilizer are shown in Fig. 2. We included manure-derived $\mathrm{N}$ in our total $\mathrm{N}$ input estimates, but did not map this input to protect the identity of the small number of individual CAFOs in the area. For the entire CRW, annual $\mathrm{N}$ input rate was $89 \mathrm{~kg} \mathrm{~N} \mathrm{ha}^{-1}$ year $^{-1}$, with $90 \%$ of this input coming from agricultural fertilizer (80 kg N ha ${ }^{-1}$ year $^{-1}$, Table 1). Atmospheric deposition was the second largest contributor, accounting for $5 \%$ of total $\mathrm{N}$ input $\left(5 \mathrm{~kg} \mathrm{~N} \mathrm{ha}^{-1}\right.$ year $\left.^{-1}\right)$. Agricultural $\mathrm{BNF}$ was the third largest input, with a rate of $2 \mathrm{~kg} \mathrm{~N} \mathrm{ha}^{-1}$ year $^{-1}$, followed by red alder BNF at a rate of $1 \mathrm{~kg} \mathrm{~N} \mathrm{ha}^{-1}$ year $^{-1}$ across the entire watershed. Input of $\mathrm{N}$ from manure, non-farm fertilizer, and septic systems accounted for a small portion in the $\mathrm{CRW}$, together accounting for $<1 \mathrm{~kg} \mathrm{~N} \mathrm{ha}^{-1}$ year $^{-1}$ and $<0.5 \%$ of inputs (Table 1). Input from nonsewered septic waste was not plotted in Fig. 2 because the contribution was negligible.

Substantial variability in $\mathrm{N}$ inputs was observed across the watershed (Fig. 2). Among subwatersheds, agricultural fertilizer input varied between 0 and 

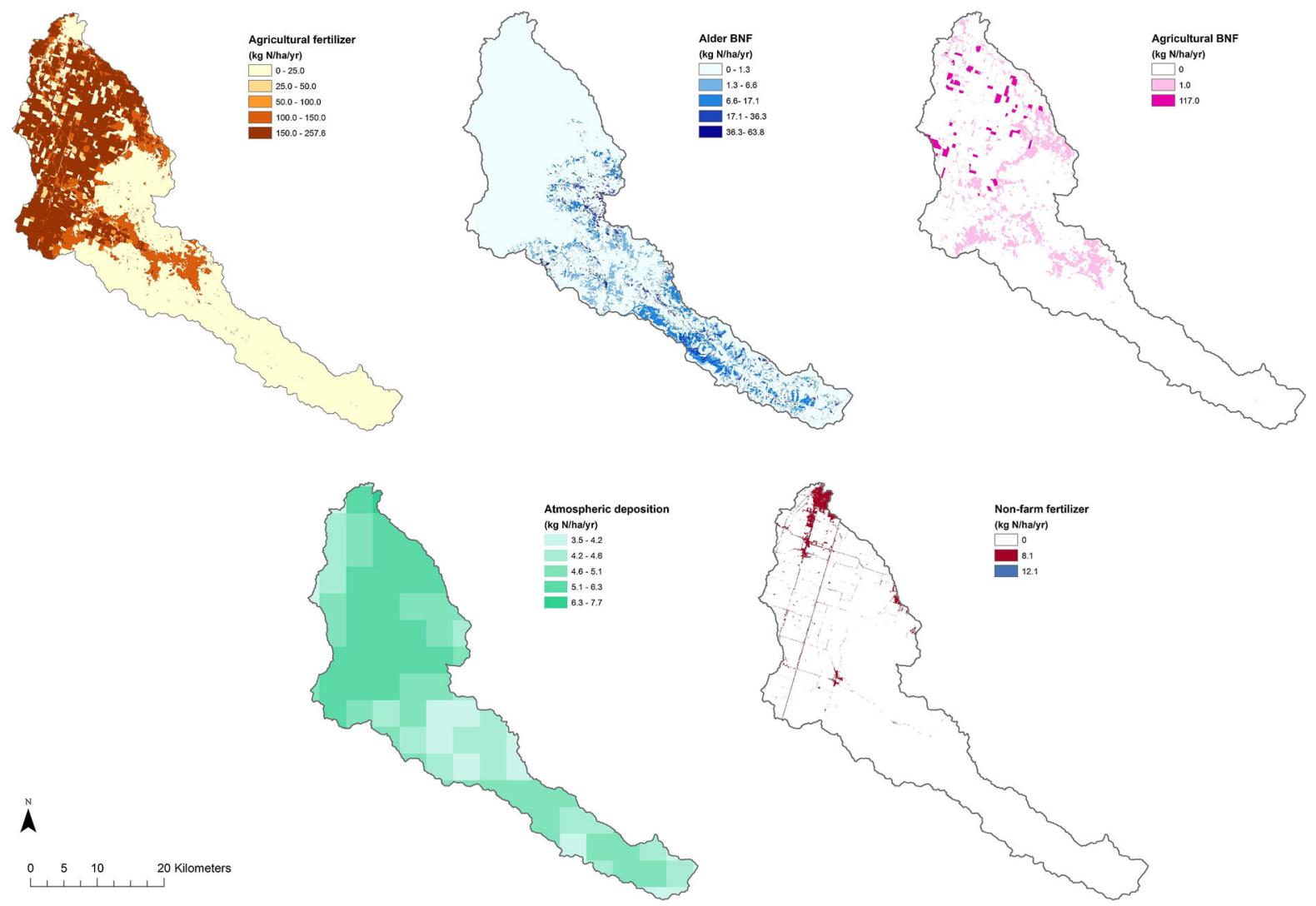

Fig. 2 Distribution of nitrogen $(\mathrm{N})$ input rates to the Calapooia River Watershed. Nitrogen sources are: agricultural fertilizer, alder biological $\mathrm{N}$ fixation (BNF), agricultural BNF,

$183 \mathrm{~kg} \mathrm{~N} \mathrm{ha}^{-1}$ year $^{-1}$. In the agriculturally dominated subwatersheds, the contribution of fertilizer input as a percentage of total $\mathrm{N}$ input ranged between 45 and $97 \%$, and the total input rate ranged between 51 and $183 \mathrm{~kg} \mathrm{~N}^{-1} \mathrm{year}^{-1}$. In the forested mountains, $\mathrm{N}$ input was typically $<10 \mathrm{~kg} \mathrm{~N} \mathrm{ha}^{-1}$ year $^{-1}$, with atmospheric deposition and alder BNF being the two main sources (Fig. 3). For intermediate slope subwatersheds where Christmas trees and pasture are intermixed with forestland, $\mathrm{N}$ inputs ranged between 15-30 kg N ha ${ }^{-1}$ year $^{-1}$.

Outputs in streams and crop removal

Annual stream export of $\mathrm{TN}$ ranged from $<1$ to $57 \mathrm{~kg} \mathrm{~N}^{-1}$ year $^{-1}$ among the 58 tributary subwatersheds, with $\mathrm{TN}$ concentration ranging from $<0.01$ to $43 \mathrm{mg} \mathrm{L}^{-1}$ (Fig. 4); the highest rate of stream $\mathrm{N}$ export occurred in the lower, agriculturally-dominated atmospheric $\mathrm{N}$ deposition, and non-farm fertilizer (the linear features are roads in the watershed)

part of the watershed. Annual export from mainstem sections of the river generally increased downstream and ranged from 2.1 to $25.9 \mathrm{~kg} \mathrm{~N} \mathrm{ha}^{-1}$ year $^{-1}$. Stream $\mathrm{N}$ export was less than $5 \mathrm{~kg} \mathrm{~N} \mathrm{ha}^{-1}$ year $^{-1}$ on the forested portion of the CRW. For all the tributary subwatersheds combined, annual stream export of $\mathrm{N}$ in the CRW was $19 \%$ of total annual $\mathrm{N}$ input, and $31 \%$ of annual surplus $\mathrm{N}$.

$\mathrm{N}$ removed via crop harvest was $<1 \mathrm{~kg} \mathrm{~N}^{-1}$ year ${ }^{-1}$ in forested watersheds overall (Fig. 5). Crop harvest ranged widely from 6 to $75 \mathrm{~kg} \mathrm{~N} \mathrm{ha}^{-1}$ year $^{-1}$ on the agriculturally-dominated landscape, reflecting variations in cover type within the watershed (Fig. 6a). Annual crop removal was very strongly correlated with total $\mathrm{N}$ inputs $\left(\mathrm{r}^{2}=0.98\right.$, Fig. 5a). Based on the regression slope, an average of $41 \%$ of total $\mathrm{N}$ input was removed via crop harvest annually among the 58 subwatersheds. 

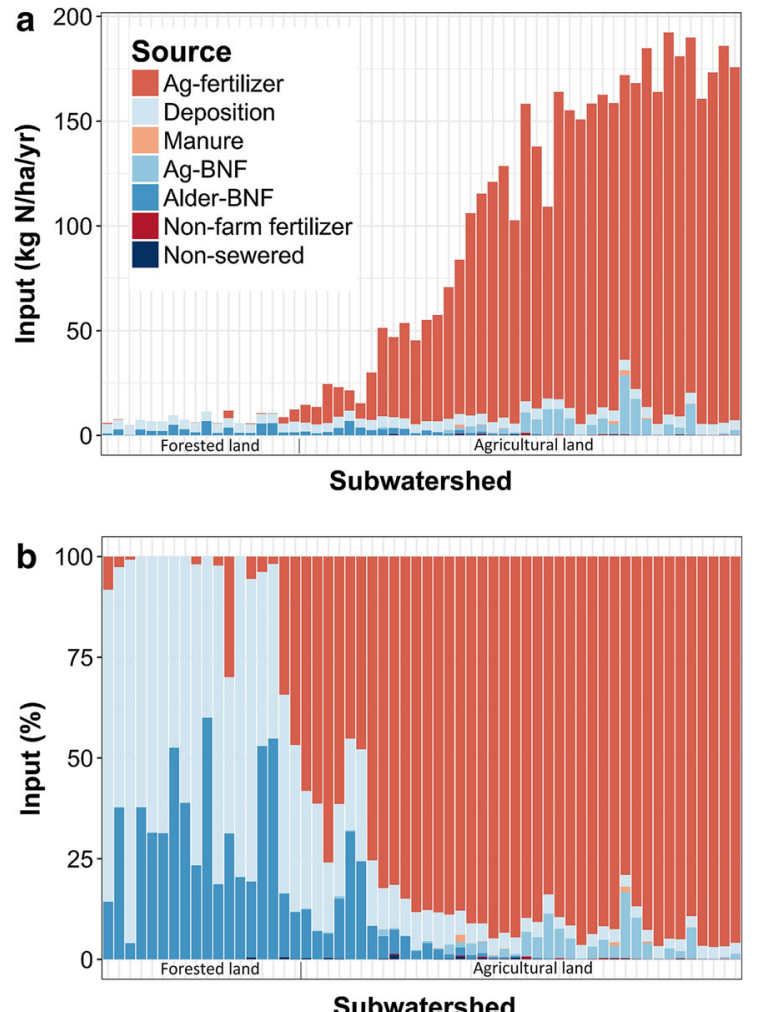

Fig. 3 Annual input rates (a: $\mathrm{kg} \mathrm{N} \mathrm{ha}^{-1} \mathrm{yr}^{-1}$ ) and percent contributions (b) of seven nitrogen $(\mathrm{N})$ sources of the monitored subwatersheds in the Calapooia River Watershed. Subwatersheds are oriented from lowest to highest percent agriculture along the $\mathrm{x}$-axis. Percent agricultural land ranges from 0 to $<15 \%$ for subwatersheds defined as forestland, and from 15 to $93 \%$ for agricultural land

The ratio of harvest removal to stream export $\mathrm{N}$ $(\Delta \mathrm{N})$, as an indicator of $\mathrm{N}$ Use Efficiency (NUE), is closely related to land use and total input (Fig. $5 \mathrm{~d}$ ). $\Delta \mathrm{N}$ greater than 1 indicated crop harvest removed more $\mathrm{N}$ than stream export. Subwatersheds dominated by pasture land and some of the grass seed cropland had higher $\Delta \mathrm{N}$ values $(>2)$. However, $\Delta \mathrm{N}$ value was approaching 1 for some intensively cultivated grass seed crops. In general, $\Delta \mathrm{N}$ increased with total $\mathrm{N}$ input in the studied area until the total input exceeded $120 \mathrm{~kg} \mathrm{~N} \mathrm{ha}^{-1}$ year $^{-1}$, then $\Delta \mathrm{N}$ started to decline with enhancing input.

$\mathrm{N}$ balance remaining in the watershed

Annual surplus $\mathrm{N}\left(\mathrm{N}_{\text {sur }}\right.$, Eq. 2$)$ in the $\mathrm{CRW}$ ranged from $<0$ to $>150 \mathrm{~kg} \mathrm{~N}^{-1}$ year $^{-1}$ (Fig. 7). Agricultural subwatersheds were characterized by annual a

$\Lambda^{N}$

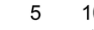

10

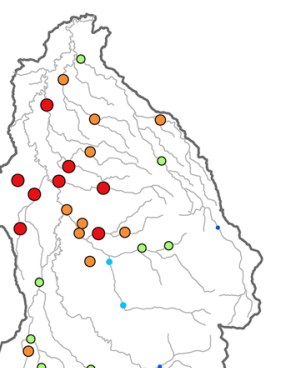

Tributary sites

Annual yield (kg N/ha/yr)

. $\quad 0.5-5.0$

- $5.0-10.0$

- $10.0-20.0$

- $20.0-35.0$

- $\quad 35.0-57.3$

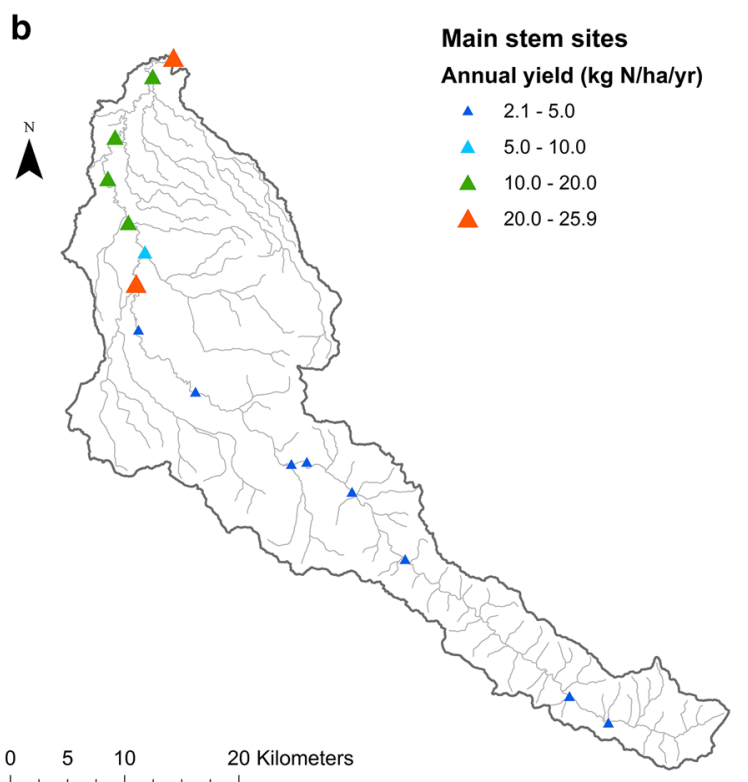

Fig. 4 Annual stream export of nitrogen for a Calapooia River subwatersheds (circles), and b Calapooia River mainstem sites (triangles)

surplus $\mathrm{N}$ values $>50 \mathrm{~kg} \mathrm{~N} \mathrm{ha}^{-1}$ year $^{-1}$. Some but not all of the highest surplus $\mathrm{N}$ areas were associated with animal waste input. Most forested subwatersheds were in a steady state with the annual surplus $\mathrm{N}$ ranging between 0 and $15 \mathrm{~kg} \mathrm{~N} \mathrm{ha}^{-1}$ year $^{-1}$. The exception was in areas where $\mathrm{N}$-fixing alder trees were 
Fig. 5 Nitrogen relationships in the Calapooia River Watershed, 2008. a Annual crop removal of nitrogen (N) versus total $\mathrm{N}$ input. b Remainder $\mathrm{N}$ versus total $\mathrm{N}$ input. c Annual stream export of $\mathrm{N}$ versus total $\mathrm{N}$ input. d The ratio of crop removal to stream export $(\Delta \mathrm{N})$ versus total $\mathrm{N}$ input; red dashed line: $\Delta \mathrm{N}=1$.

The grey band in each figure is the $95 \%$ confidence level interval. Land use: $E V F$ evergreen forest, ITR Italian rye grass, $P R R$ perennial rye grass, $P S T$ pasture; $R F R$ reforestation and Christmas trees
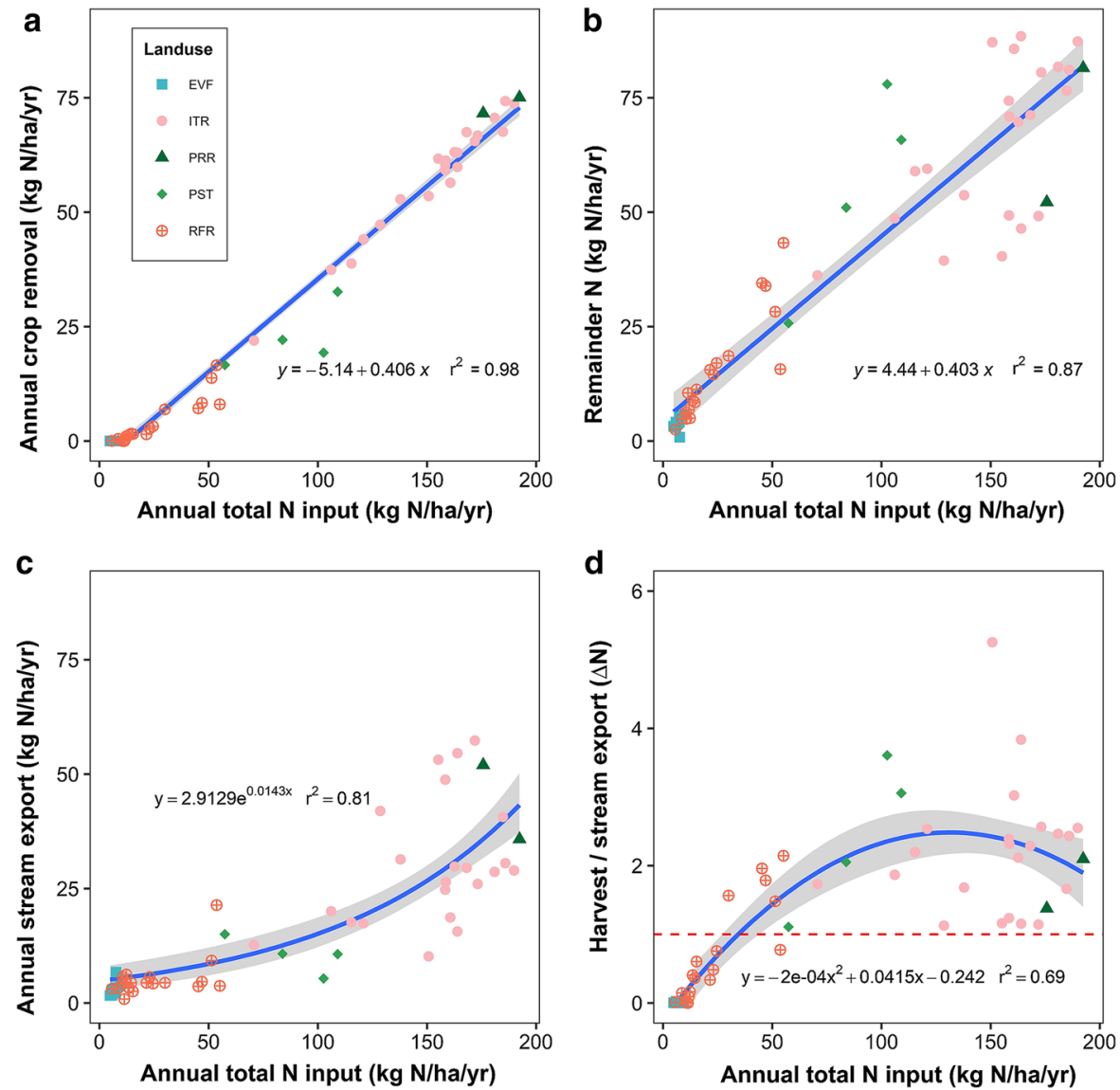

prevalent, resulting in $\mathrm{N}$ surplus estimates reaching $50 \mathrm{~kg} \mathrm{~N} \mathrm{ha}^{-1}$ year $^{-1}$ (Fig. 7).

Substantial variation in the amount of remainder $\mathrm{N}$ (Eq. 3) was observed on agricultural subwatersheds, ranging between 11 and $89 \mathrm{~kg} \mathrm{~N}^{-1}$ year $^{-1}$, with a mean of $53 \mathrm{~kg} \mathrm{~N}^{-1}$ year $^{-1}$ (Fig. $5 \mathrm{~b}$ and $6 \mathrm{a}$ ). Based on the regression slope, remainder $\mathrm{N}$ was similar in magnitude to crop uptake, representing $40 \%$ of total $\mathrm{N}$ input across the CRW $\left(\mathrm{r}^{2}=0.87\right.$, Fig. $\left.5 \mathrm{~b}\right)$ and $69 \%$ of annual surplus $\mathrm{N}\left(\mathrm{r}^{2}=0.90\right)$.

\section{Seasonal N fluxes}

Nitrogen inputs to the CRW varied strongly by season: $50 \%$ of nitrogen input occurred in the winter (usually late February), $24 \%$ in the spring, $23 \%$ in the fall, and $<4 \%$ in the summer (Fig. 8 a). These seasonal proportions were driven by synthetic fertilizer input. Atmospheric deposition was the second largest input source of $\mathrm{N}$ in the $\mathrm{CRW}$ with highest deposition rates occurring in summer and lowest in winter.
For the entire CRW, $71 \%$ of the watershed stream N export occurred during winter months (peaked during December and January), and very little stream $\mathrm{N}$ export occurred in summer $(<1 \%$; Figs. $8 \mathrm{~b}$ and 9$)$. The onset of winter stream export, however, occurred prior to the period of largest fertilizer input in the watershed. In the mountainous forested subwatersheds, $54 \%$ of stream $\mathrm{N}$ export occurred in winter, $24 \%$ in the fall, $20 \%$ of in spring and $2 \%$ in the summer. In agricultural subwatersheds, mean stream $\mathrm{N}$ export was respectively $64 \%, 30 \%, 6 \%$ and $<1 \%$ in winter, fall, spring and summer (Fig. 9). Winter was the dominant season for hydrological export of $\mathrm{N}$, but there was also substantial stream export in both fall and spring.

At the watershed scale, remainder $\mathrm{N}$ (Eq. 3) was highest during winter $\left(29 \mathrm{~kg} \mathrm{~N} \mathrm{ha}^{-1}\right)$, and lowest during summer (- $24 \mathrm{~kg} \mathrm{~N} \mathrm{ha}^{-1}$ ) (Fig. 8c). Approximately $92 \%$ of $\mathrm{N}$ export via crop harvest happened in summer, followed by spring (5\%) and fall harvest (3\%) (Fig. 8b). 

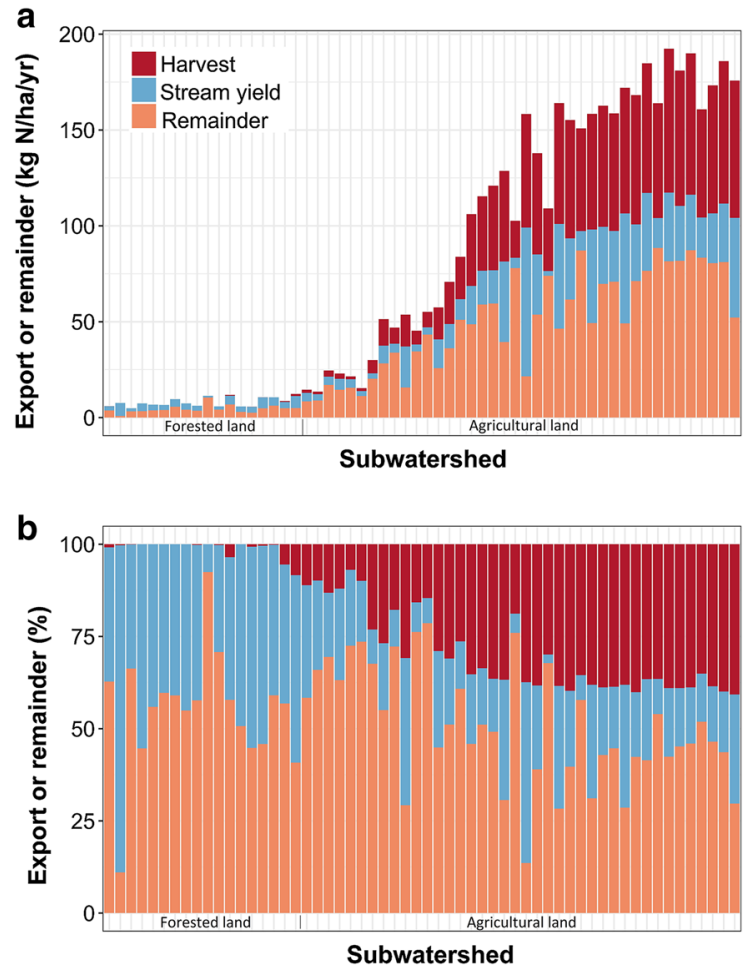

Fig. 6 Annual nitrogen harvest, stream export and remainder rates $\left(\mathbf{a}: \mathrm{kg} \mathrm{N} \mathrm{ha}^{-1} \mathrm{yr}^{-1}\right.$ ) and percentages (b) in the subwatersheds of the Calapooia River Watershed. Subwatersheds are oriented from lowest to highest percent agriculture along the $\mathrm{x}$-axis

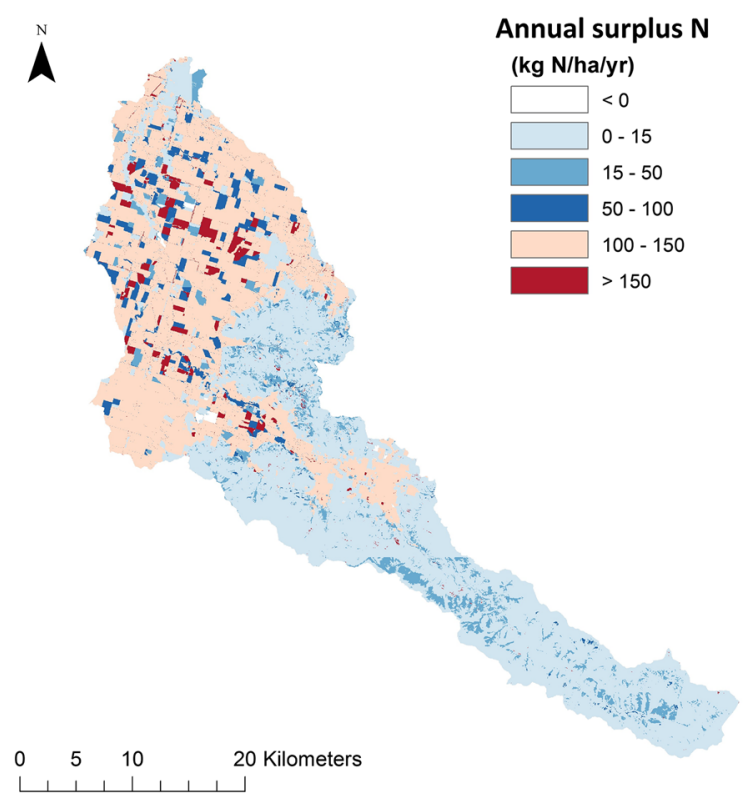

Fig. 7 Annual surplus nitrogen (total input minus crop harvest nitrogen) in the Calapooia River Watershed
Linear regression analysis of seasonal stream export

The results demonstrated that there could be a time lag between $\mathrm{N}$ input and hydrologic export. Winter (January to March) fertilization exhibited a stronger impact on fall stream $\mathrm{N}$ export $\left(\mathrm{r}^{2}=0.66, \mathrm{p}<0.0001\right)$ rather than on spring and summer export $\left(\mathrm{r}^{2}\right.$ values of both are 0.38). Fall (October-December) inputs of fertilizer did not explain much of the variability in fall stream $\mathrm{N}$ exports. Legacy $\mathrm{N}$ from previous seasons (winter and spring) and summer crop removal appear to have a greater influence on fall stream export (Table 2). Winter fertilization alone explained $60 \%$ of the variation in winter stream $\mathrm{N}$ export. On average, an equivalent of $24 \%$ of winter fertilizer was removed via winter stream export.

\section{Discussion}

The mitigation of air and water quality issues caused by $\mathrm{N}$ release to the environment relies upon quantitative analysis of the source and fate of $\mathrm{N}$, which can be aided by constructing a comprehensive $\mathrm{N}$ budget. Watershed budgets allow direct comparison among watersheds in different regions, and enhance our understanding of how land use and management activities can alter nutrient fluxes and the environmental consequences. Constructing a seasonal budget can further improve our understanding on the timing of nutrient losses and help establish better management practices for the future. This work provides one of the first seasonal, locally derived $\mathrm{N}$ input-output budgets for a large mixed management watershed.

Comparison with other watersheds

As a predominantly agricultural watershed, the CRW fertilizer input rate of $80 \mathrm{~kg} \mathrm{~N}^{-1}$ year $^{-1}$, representing $90 \%$ of $\mathrm{N}$ inputs, was comparable to other US watersheds (Boyer et al. 2002; Schaefer and Alber 2007; Sobota et al. 2009; Schaefer et al. 2009). Annual fertilizer input among CRW subwatersheds ranged from $<1$ to $>180 \mathrm{~kg} \mathrm{~N} \mathrm{ha}^{-1}$ year $^{-1}$ in 2008 , generally higher than fertilizer contributions in 22 previously studied watersheds on the west coast $(<1$ to $30 \mathrm{~kg} \mathrm{~N} \mathrm{ha}^{-1}$ year $^{-1}$; Schaefer et al. 2009). However, the watersheds in Schaefer et al. (2009) had a lower 

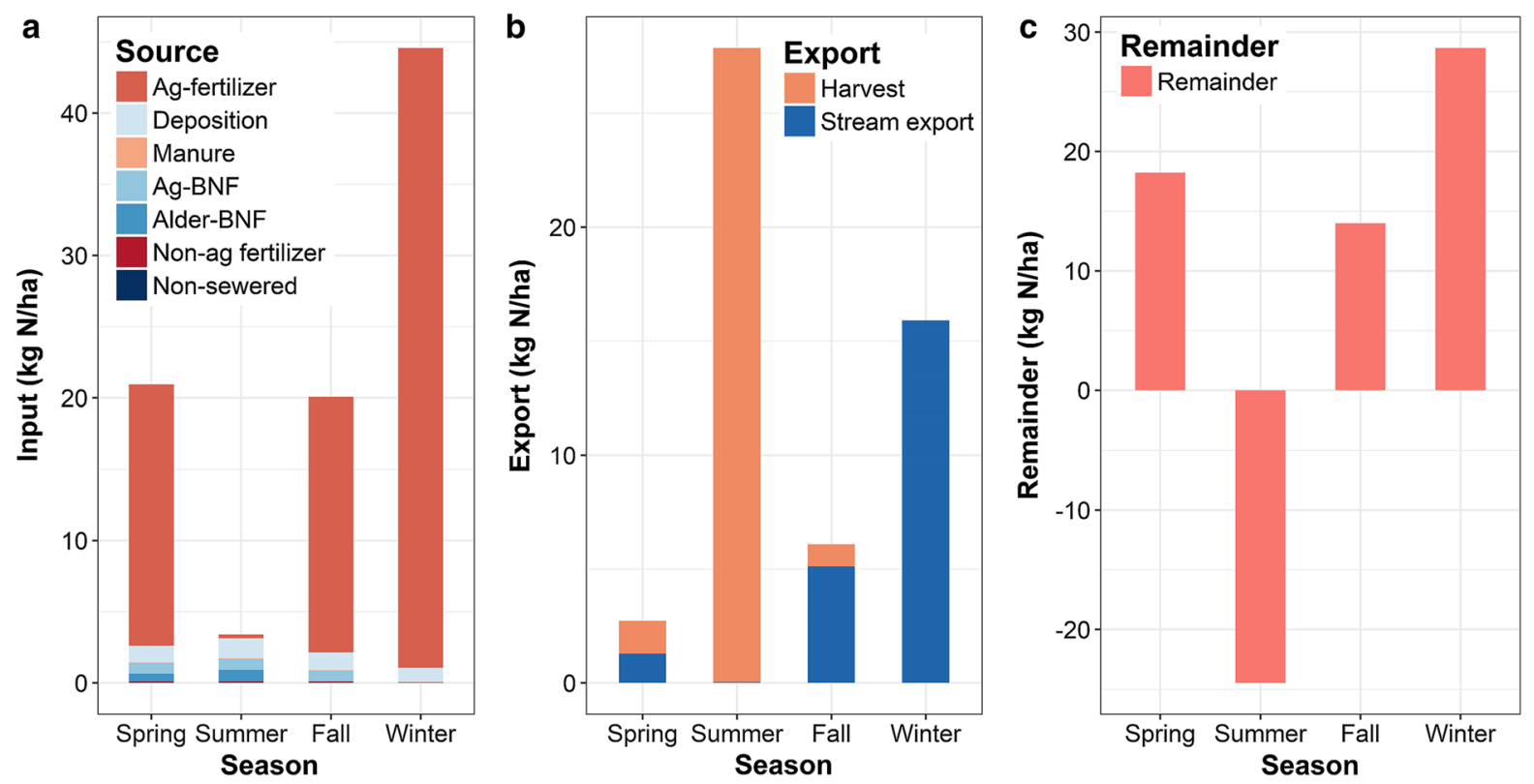

Fig. 8 a Seasonal nitrogen $(\mathrm{N})$ input rates by source. b Seasonal N export rates via crop removal and stream flux. c Seasonal remainder $\mathrm{N}$ in the Calapooia River Watershed. Negative remainder $\mathrm{N}$ rate in summer indicates a net seasonal $\mathrm{N}$ loss due to harvest
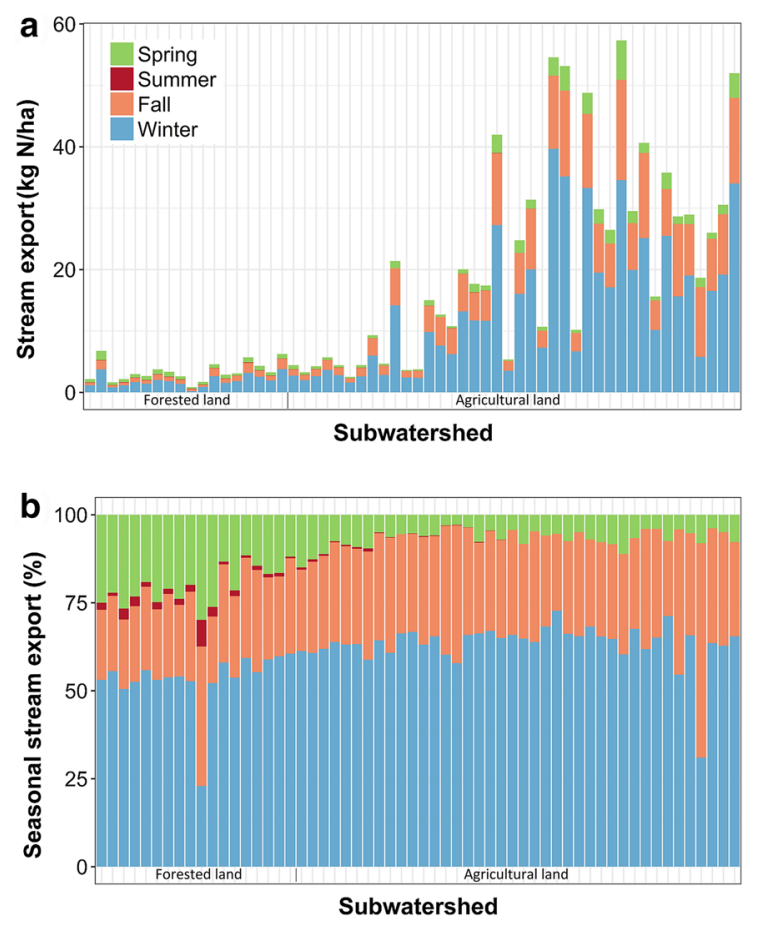

Fig. 9 Stream export of nitrogen in each season (a) and seasonal export fraction (b) in the Calapooia River subwatersheds. Subwatersheds are oriented from lowest to highest percent agriculture along the $\mathrm{x}$-axis percent agricultural land $(<30 \%)$ compared to the CRW (53\% agriculture). The highest fertilizer rate calculated for 21 California watersheds was approximately $75 \mathrm{~kg} \mathrm{~N}^{-1}$ year $^{-1}$ for the Salt/Mud Slough Watershed with 74\% agricultural land (Sobota et al. 2009), estimated based on inorganic $\mathrm{N}$ fertilizer county-level sales data in 1991. According to a recent USGS report on farm $\mathrm{N}$ usage, fertilizer application rate in the same county had increased to $90 \mathrm{~kg} \mathrm{~N} \mathrm{ha}^{-1}$ year $^{-1}$ in 2008 (Brakebill \& Gronberg 2017), similar to the $80 \mathrm{~kg} \mathrm{~N}^{-1}$ year $^{-1}$ fertilizer input rate in CRW.

Stream N export from CRW forested subwatersheds was less than $10 \mathrm{~kg} \mathrm{~N} \mathrm{ha}^{-1}$ year $^{-1}$ and averaged $3 \mathrm{~kg} \mathrm{~N}^{-1}$ year $^{-1}$, comparable to forested watersheds in other studies (Boyer et al. 2002; Schaefer and Alber 2007). However, regarding agricultural subwatersheds, the CRW value (average of $22 \mathrm{~kg} \mathrm{~N} \mathrm{ha}^{-1}$ year $^{-1}$ ) was 1-2 times higher than in other regions (Sobota et al. 2009; Boyer et al. 2002; Schaefer and Alber 2007; Sigler et al. 2018). CRW values are more similar to field-level nitrate leaching fluxes of $24 \mathrm{~kg} \mathrm{~N}^{-1}$ year $^{-1}$ from tile drained wheat fields in eastern Washington (Kelley et al. (2013), and $\mathrm{N}$ export of $18 \mathrm{~kg} \mathrm{~N}^{-1}$ year $^{-1}$ in Montana agricultural basins (Sigler et al. 2018). Upper Missouri River basin watersheds of Montana also had a high 
Table 2 Regression results of factors influencing annual and seasonal stream nitrogen $(\mathrm{N})$ export in agricultural tributaries of the Calapooia River Watershed $(\mathrm{n}=37)$

\begin{tabular}{|c|c|c|c|c|c|}
\hline \multirow[t]{2}{*}{ Explanatory variables } & \multirow{2}{*}{$\begin{array}{l}\text { Annual stream } \mathrm{N} \text { export } \\
\left(\mathrm{r}^{2} \text { and significance levels }{ }^{\mathrm{a}}\right)\end{array}$} & \multicolumn{4}{|c|}{ Seasonal stream $\mathrm{N}$ export $\left(\mathrm{r}^{2}\right.$ and significance levels $\left.{ }^{\mathrm{a}}\right)$} \\
\hline & & Winter & Spring & Summer & Fall \\
\hline \multicolumn{6}{|l|}{ Total seasonal $\mathrm{N}$ input } \\
\hline Spring & $0.36 * * *$ & na & 0.24 & $0.27 * *$ & $0.45 * * *$ \\
\hline Summer & 0.13 & na & na & ns & ns \\
\hline Fall & $0.26^{*}$ & na & na & na & $0.29 * *$ \\
\hline Winter & $0.63 * * *$ & $0.60 * * *$ & $0.39 * * *$ & $0.39 * * *$ & $0.66^{* * *}$ \\
\hline \multicolumn{6}{|l|}{ Seasonal $\mathrm{N}$ removal via harvest } \\
\hline Spring & 0.02 & na & ns & ns & ns \\
\hline Summer & $0.62 * * *$ & na & na & $0.35 * * *$ & $0.67 * * *$ \\
\hline Fall & $0.19 *$ & na & na & na & $\mathrm{ns}$ \\
\hline Winter & na & na & na & na & na \\
\hline \multicolumn{6}{|l|}{ Seasonal fertilizer $\mathrm{N}$ input } \\
\hline Spring & $0.32 * *$ & na & 0.19 & 0.26 & $0.42 * * *$ \\
\hline Summer & 0.02 & na & na & ns & ns \\
\hline Fall & 0.17 & na & na & na & 0.21 \\
\hline Winter & $0.63 * * *$ & $0.60 * * *$ & $0.38 * * *$ & $0.39 * * *$ & $0.66 * * *$ \\
\hline NETWinter $^{\mathrm{b}}$ & na & $0.60 * * *$ & $0.39 * * *$ & $0.39 * * *$ & $0.66^{* * *}$ \\
\hline NETSpring $^{\mathrm{c}}$ & $0.35^{* *}$ & na & 0.23 & 0.25 & $0.45^{* * *}$ \\
\hline NETWinter + Spring $^{\mathrm{d}}$ & $0.39 * * *$ & na & 0.22 & $0.37 * * *$ & $0.49 * * *$ \\
\hline NETSummer ${ }^{\mathrm{e}}$ & $0.59^{* * *}$ & na & na & $0.34 * *$ & $0.64 * * *$ \\
\hline NETWinter + Spring + Summer $^{\mathrm{f}}$ & 0.09 & na & na & 0.33 & 0.19 \\
\hline NETFall $^{\mathrm{g}}$ & $0.32 * *$ & na & na & na & $0.35^{* * *}$ \\
\hline NETWinter + Spring + Summer + Fall $^{\mathrm{h}}$ & $0.18 *$ & na & na & na & $0.27 * *$ \\
\hline
\end{tabular}

Explanatory variables include total seasonal $\mathrm{N}$ input, seasonal harvest and fertilizer input, and accumulated 'NET' input from previous seasons. Winter (January to March) is the first season in the analysis, and fall the last season

${ }^{a}$ Significance levels: $* * * \mathrm{p}<0.0001, * * \mathrm{p}<0.001$; number without '*' sign: $\mathrm{p}<0.01$, ns not significant, na analyses not carried out because later season has no impact on earlier seasons in the year

${ }^{\mathrm{b}}$ NETWinter $=$ Winter surplus $\mathrm{N}=$ Total input of $\mathrm{N}$ (winter) - Crop removal (winter); because winter crop removal equals 0 in our seasonal calculation, NETWinter is equal to total winter input of $\mathrm{N}$

${ }^{\mathrm{c}}$ NETSpring $=$ Spring surplus $\mathrm{N}=$ Total input of $\mathrm{N}$ (spring) - Crop removal (spring)

${ }^{\mathrm{d}}$ NETWinter + Spring $=$ Total input of $\mathrm{N}($ winter + spring $)-$ Stream export (winter) - Crop removal (winter + spring)

${ }^{\mathrm{e}}$ NETSummer $=$ Summer surplus $\mathrm{N}=$ Total input of $\mathrm{N}$ (summer) - Crop removal (summer)

${ }^{\mathrm{f}}$ NETWinter + Spring + Summer $=$ Total input of $\mathrm{N}$ (winter + spring + summer $)-$ Stream export $($ winter + spring $)-$ Crop removal (winter + spring + summer)

${ }^{\mathrm{g}} \mathrm{NETFall}=$ Fall surplus $\mathrm{N}=$ Total input of $\mathrm{N}$ (fall) - Crop removal (fall)

${ }^{\mathrm{h}}$ NETWinter + Spring + Summer + Fall $=$ Total input $\quad$ of $\quad \mathrm{N} \quad($ winter + spring + summer + fall $)-$ Stream $\quad$ export $($ winter + spring + summer $)-$ Crop removal $($ winter + spring + summer + fall $)$

proportion of fertilizer inputs exported $(19-31 \%$ of added fertilizer; Sigler et al. 2018), similar to the CRW. The coincidence of late winter fertilization with predominantly winter rains and wet or saturated soils could be important drivers of the high $\mathrm{N}$ export rate and proportion in the following seasons in parts of the western US and other similar climates. 
Remainder $\mathrm{N}$ averaged $53 \mathrm{~kg} \mathrm{~N}$ ha $^{-1}$ year $^{-1}$ for agriculturally-dominated subwatersheds in CRW, falling within the same range of estimates for some California watersheds. Using published data from Sobota et al. (2009), we estimated similar values for remainder $\mathrm{N}$ in the Colusa (54\% agricultural land) and Upper San Joaquin River Basins (30\% agricultural land), respectively $42 \mathrm{~kg} \mathrm{~N}^{-1}$ year $^{-1}$ and $55 \mathrm{~kg} \mathrm{~N}^{-1}$ year $^{-1}$.

Impact of watershed management on nitrogen export and balances

While both stream export and crop removal increased with total $\mathrm{N}$ input, the relationship between these two export paths was also a function of specific land use types and input rates. As shown in Fig. 5d, the ratio of harvest:stream $\mathrm{N}$ fluxes $(\Delta \mathrm{N})$ increases then decreases with $\mathrm{N}$ inputs. In evergreen forest subwatersheds, stream export exceeded harvest removal since crop harvest is minimal in these watersheds; we did not have information about forest harvest, but wood removal is expected to take little $\mathrm{N}$ off site. As $\mathrm{N}$ inputs increase, crop harvest also increases leading to a maximum $\Delta \mathrm{N}$ of approximately $2: 1$. Then as total $\mathrm{N}$ input continues to increase with higher fertilizer inputs across the entire watershed, $\Delta \mathrm{N}$ values diminished drastically on several watersheds dominated by grass seed fields. $\Delta \mathrm{N}$ was close to 1 in these subwatersheds where total input exceeded $150 \mathrm{~kg} \mathrm{~N} \mathrm{ha}^{-1}$ year $^{-1}$, and the increase in $\mathrm{N}$ export via stream flow (as indicated by the exponential trend in Fig. 5c) was faster than the enhancement in crop uptake. As $\mathrm{N}$ inputs continue to increase above $150 \mathrm{~kg} \mathrm{~N}^{-1}$ year $^{-1}$, we start seeing a decline in ecosystem $\mathrm{N}$ retention relative to stream export indicating a saturation of uptake (e.g., Perakis et al. 2005). This saturation could be related to timing of inputs. Like many other grass seed crops, Italian ryegrass and perennial ryegrass required additional fertilization in fall to guarantee seed production. Even though fall fertilizer was applied at a relatively small rate (around $45 \mathrm{~kg} \mathrm{~N} \mathrm{ha}^{-1}$ ), it had a significant impact on $\mathrm{N}$ export. A closer monitoring of crop growth and synchrony between applied and soil available (mineralized) nutrient supply and demand is necessary to reduce hydrological loss of $\mathrm{N}$ in agricultural watersheds (Arregui and Quemada 2008; Quemada et al. 2013).
Total annual stream export of $\mathrm{N}$ was well correlated with winter fertilizer input $\left(r^{2}=0.63\right.$; Table 2$)$, which was the dominant source of annual $\mathrm{N}$ input to the CRW. Annually, $\mathrm{N}$ loss to the CRW tributaries was equivalent to $40 \%$ of fertilizer applied in the winter months in the entire CRW. As shown in Fig. 9b, agricultural subwatersheds had higher percentages of seasonal stream export in winter but lower seasonal stream export in spring compared to forested subwatersheds. This shift in seasonality of stream export could be attributed to winter fertilization to crop land. The summer fraction of stream export was higher in the forested, mountainous subwatersheds compared to the flat agricultural land, presumably as a result of summer runoff in the mountains that has been linked to high elevation sources and snowmelt (Brooks et al. 2012). Denitrification accounted for only $0-6.8 \%$ of stream nitrate moving through southern Willamette Valley streams (Sobota et al. 2012), and thus we assume that benthic denitrification is a relatively small sink for $\mathrm{N}$ exported to streams.

The highest export in streams occurred in December to January, prior to the period of largest fertilizer input in February through April. Nitrogen applied in "late winter" was by far the largest input, but these $\mathrm{N}$ inputs were used by the growing crop, and not flushed out until the next fall and winter. Seasonal input and removal were relatively unimportant for spring stream export (Table 2), indicating a portion of $\mathrm{N}$ entering streams in the spring was a legacy from previous seasons, originating from more unused or transformed fertilizer N. Fall mineralization and mobilization of organic matter from previous crops and late summer/fall tillage operations can generate additional nitrate: Alva et al. (2002) found that cumulative $\mathrm{N}$ mineralized in sandy soils could range between 72 to $172 \mathrm{~kg} \mathrm{~N} \mathrm{ha}^{-1}$ during January through September on PNW crop land with the highest mineralization potential occurring in January. This may help explain why winter was the highest stream export month even though more fertilizer was applied late winter/early spring on grass seed crops. Cumulative soil $\mathrm{N}$ from previous growing seasons or years could also help explain the net summer removal of $\mathrm{N}$ expressed as the negative remainder $\mathrm{N}$ on Fig. 8c.

High net removal of $\mathrm{N}$ in summer did not prevent high $\mathrm{N}$ loss to streams in fall. On the contrary, summer harvest $\mathrm{N}$ removal was positively correlated with fall stream export $\left(r^{2}=0.67\right)$. We also found a good 
correlation between fall stream export and $N E T_{\text {Summer }}$ $\left(\mathrm{r}^{2}=0.64\right)$, connecting high stream loss to intensive cultivation that increased residual $\mathrm{N}$ accumulating from previous seasons. The results suggested that inorganic $\mathrm{N}$ accumulated in the soil during the dry period after harvest removal, and crop growth in the fall was too slow to capture all the $\mathrm{N}$ prior to leaching loss. Furthermore, the drying and wetting cycles of soil appear to facilitate fall stream export. Fall precipitation recharged the dry soil and caused the rise of groundwater level in the CRW (Conlon et al. 2005), perhaps moving the $\mathrm{N}$ out before it could be taken up by the re-growing grass. As a result, remobilized inorganic $\mathrm{N}$ could run off into intermittent and ephemeral streams during fall and winter (Wigington et al. 2003). We estimate that an equivalent of $10 \%$ of winter plus spring fertilizer $\left(6 \mathrm{~kg} \mathrm{ha}^{-1}\right)$ was exported via CRW streams in the following fall.

Temporal disconnects between $\mathrm{N}$ supply, movement, and sinks within agricultural systems can result in inefficiency in $\mathrm{N}$ use (Robertson and Vitousek 2009). Current crop management across the US is tending toward more synchrony between crop demand and supply of nutrients, to increase uptake efficiency and reduce losses to the environment (Cassman et al. 2002). Possible practices designed to improve on-field nutrient management include variable rate applications, split applications of fertilizer timed to crop demand, incorporation of manure, irrigation water and soil nitrate as additional sources of $\mathrm{N}$, improvements in irrigation practices, and use of nitrification inhibitors (Ferguson 2015; Fernández et al. 2016; Lacey and Armstrong 2015). An interview study of farmers across the US that included farmers in the Calapooia Basin indicates that farmers generally did not apply nutrient management plans, soil testing or extension recommendations, but the study found increased adoption of these practices when combined with watershed education and funding for nutrient management (Osmond et al. 2014). More communication and outreach may be needed for the increased adoption and effectiveness of these practices in the Willamette Valley.

Uncertainties in riparian buffers and tile drains

Use of cover crops and expansion of riparian buffers have been widely proposed as means to reduce $\mathrm{N}$ export to groundwater or streams (Dabney et al. 2010).
Some work calls into question riparian buffer expansion as a significant mechanism for reducing hydrologic $\mathrm{N}$ loading to groundwater and streams in the Willamette River Basin (Davis et al. 2008; Wigington et al. 2005). For example, grass seed crops retained a much higher proportion of added ${ }^{15} \mathrm{~N}$ than riparian buffers: after 14 months, about $29-34 \%$ of added ${ }^{15} \mathrm{~N}$ in perennial ryegrass systems in the CRW remained in soils $(0-30 \mathrm{~cm})$, but only $12-17 \%$ remained in riparian soils (Davis et al. 2008). Lower $N$ storage in riparian soils was attributed to flooding and drying events that reduced plant uptake and may have increased the potential of $\mathrm{N}$ loss through overland flow (Davis et al. 2006). Also, in the flat Willamette Valley topography, $\mathrm{N}$ bypasses riparian zones by moving from cropland into expanded stream networks during large winter hydrologic events (Wigington et al. 2005). Riparian zones have less impact on $\mathrm{N}$ reduction when flow occurs across the surface and has little interaction with plant roots and organic-rich riparian soils. Hydrologic factors may result in a bypassing of riparian buffers, constraining their ability to remove $\mathrm{N}$ and reduce $\mathrm{N}$ export in the $\mathrm{CRW}$.

Due to the lack of spatial information on tile drainage, we currently are unable to incorporate the effects of tile drain systems into the analysis. However, tile drainage could be a significant component of $\mathrm{N}$ export in the CRW. While denitrification can occur in tile drains when flow is slow during dry periods, high concentrations of nitrate have also been found in tile drains that intercept waters and bypass $\mathrm{N}$ removal (Tesoriero et al. 2005). Kelley et al. (2013) found that nitrification was the dominant $\mathrm{N}$ process in a tiledrained field in Washington state, and there was no evidence of denitrification at a large scale to influence nitrate export. They also discovered the source of nitrate in tile drain water shifted seasonally from nitrified $\mathrm{NH}_{4}{ }^{+}$fertilizer during the high-discharge period to mineralized soil organic $\mathrm{N}$ during the lowdischarge season (Kelley et al. 2013). This shifting N transport dynamic in tile drains needs further investigation.

Connections between seasonal balances and annual nutrient use efficiency

For the entire US, agricultural $\mathrm{N}$ Use Efficiency (NUE), calculated as $\mathrm{N}$ removed in crop harvest divided by the sum of all $\mathrm{N}$ inputs, has ranged between 
$60-70 \%$ since the 1960s (Zhang et al. 2015). For the CRW, mean NUE of crops was $41 \%$, much lower than the US national average. The estimated $41 \%$ removal of $\mathrm{N}$ via crop harvest for the entire $\mathrm{CRW}$ is supported by other local studies of grass seed crop $\mathrm{N}$ uptake. $\mathrm{A}^{15} \mathrm{~N}$ tracer study in the CRW found that $39 \%$ of ${ }^{15} \mathrm{NH}_{4}$ and $42 \%$ of ${ }^{15} \mathrm{NO}_{3}$ were recovered in the aboveground plant biomass of perennial ryegrass that was fertilized in the winter (Davis et al. 2006). In contrast, crop N uptake efficiency was $61 \%$ and $43 \%$ for corn-soybean systems of Illinois and Iowa, respectively (David et al. 1997; Keeney and DeLuca 1993). Thus, CRW rates of uptake by grass seed crops appear to be at the lower range of those in the cornsoybean systems of the Midwestern US. Crop and soil factors may play a part in the differences in these NUE rates. Another substantial difference between western Oregon and the Illinois, where efficiencies were higher, is the strong seasonality of precipitation in the PNW (Hoag et al. 2012). Higher precipitation and runoff during the winter appears to drive higher seasonal $\mathrm{N}$ losses and lower NUE for crops in the CRW as compared to many other areas in the US.

The disconnect between crop $\mathrm{N}$ requirements, fertilizer applications and hydrologic $\mathrm{N}$ losses creates challenges for $\mathrm{N}$ management in this area. Other studies have shown that $\mathrm{N}$ leaching loss rates are relatively high for many crops in the CRW area (Selker and Rupp 2004; Young et al. 1997). MuellerWarrant et al. (2012) estimated that improvements to fertilizer management in the CRW could reduce hydrologic N export by approximately $24 \%$, which across the CRW would translate into a reduction in stream $\mathrm{N}$ export of approximately $5.6 \mathrm{~kg} \mathrm{~N} \mathrm{ha}^{-1}$ year $^{-1}$. We determined that $71 \%$ of the hydrologic export of $\mathrm{N}$ occurs during the early winter, which for grass seed slightly precedes the primary time of fertilizer application (mid-February to mid-March). Split application of fertilizer did not reduce grass seed yields (Young et al. 1997), suggesting that nutrient management could be modified in this way to improve water quality without sacrificing crop yields. Fall fertilizer application is another practice that should be carefully examined because much of the hydrologic export of $\mathrm{N}$ occurs between late fall and early winter. Development of nutrient best management practices should consider year-round $\mathrm{N}$ leaching losses and hydrologic export in order to better represent local soil conditions, hydrology and the crop growth dynamic and nutrient requirements.

Our novel analysis of seasonal input-output balances illustrates that watersheds with a Mediterranean climate can experience significant loss in wet seasons resulting in relatively low nutrient use efficiency. These watersheds can have high $\mathrm{N}$ levels delivered to ground and surface water under intensive agricultural activities (De Paz et al. 2009; Piccini et al. 2016). In order to reduce hydrologic $\mathrm{N}$ loss during wet winters, a closer examination of fertilization practices is needed to better match fertilizer inputs with crop growth and uptake, thus minimizing surplus $\mathrm{N}$ in these watersheds.

Acknowledgements We thank numerous farmers and other private landowners for access to streams in the lower watershed, and Robert Danehy of Weyerhaeuser Corporation for gaining access to streams on their lands in the upper watershed. Donald Streeter and Machelle Nelson, both formerly of USDA-ARS, conducted lab and field work, and Randy Comeleo of US EPA WED assisted with the spatial dataset. We also thank Blake Hatteberg, Lindsey Webb, David Beugli, Howard Bruner, and Marj Storm of CSS-Dynamac for stream sampling and data collection in the Calapooia. We thank Ryan Hill for providing support with spatial analysis using $\mathrm{R}$ and ArcGIS. Kara Goodwin, Jackie Brenner, and Phil Caruso provided GIS method development early in the project. The views expressed in this paper are those of the authors and do not necessarily reflect the views or policies of the United States Environmental Protection Agency.

\section{References}

Alexander RB, Johnes PJ, Boyer EW, Smith RA (2002) A comparison of models for estimating the riverine export of nitrogen from large watersheds. Biogeochemistry 54(1):295-339

Alva AK, Collins HP, Boydston RA (2002) Corn, wheat, and potato crop residue decomposition and nitrogen mineralization in sandy soils under an irrigated potato rotation. Commun Soil Sci Plant Anal 33(15-18):2643-2651

Arregui LM, Quemada M (2008) Strategies to improve nitrogen use efficiency in winter cereal crops under rainfed conditions. Agron J 100(2):277-284

Binkley D, Cromack K Jr, Baker DD (1994) Nitrogen fixation by red alder: Biology, rates, and controls. The biology and management of red alder. Oregon State University Press, Corvallis, pp 57-72

Bonn B, Wentz DA, Hinkle SR (1996) Willamette Basin, Oregon-nitrogen in streams and ground water 1980-1990. Open File Report 96-227. Available via USGS. https:// pubs.er.usgs.gov/publication/ofr96227

Boyer EW, Goodale CL, Jaworski NA, Howarth RW (2002) Anthropogenic nitrogen sources and relationships to 
riverine nitrogen export in the northeastern USA. Biogeochemistry 57(1):137-169

Brakebill JW, Gronberg JM (2017), County-level estimates of nitrogen and phosphorus from commercial fertilizer for the conterminous United States, 1987-2012: U.S. Geological Survey data release, https://doi.org/10.5066/F7H41PKX

Brooks JR, Wigington PJ, Phillips DL, Comeleo R, Coulombe R (2012) Willamette River Basin surface water isoscape $\left(\delta^{18} \mathrm{O}\right.$ and $\left.\delta^{2} \mathrm{H}\right)$ : temporal changes of source water within the river. Ecosphere 3(5):1-21

Cassman KG, Dobermann A, Walters DT (2002) Agroecosystems, nitrogen-use efficiency, and nitrogen management. AMBIO 31(2):132-140

Conlon TD, Wozniak KC, Woodcock D, Herrera NB, Fisher BJ, Morgan DS, Lee KK, Hinkle SR (2005) Ground-water hydrology of the Willamette Basin, Oregon: U.S. Geological Survey Scientific Investigations Report 2005-5168, p 83

Dabney SM, Delgado JA, Meisinger JJ, Schomberg HH, Liebig MA, Kaspar T, Mitchell J, Reeves W (2010) Using cover crops and cropping systems for nitrogen management. In: Delgado JA, Follet RF (eds) Advances in nitrogen management for water quality. Soil and Water Conservation Society, Ankeny, pp 231-282

David M, Gentry L (2000) Anthropogenic inputs of nitrogen and phosphorus and riverine export for Illinois, USA. J Environ Qual 29(2):494-508

David MB, Gentry LE, Kovacic DA, Smith KM (1997) Nitrogen balance in and export from an agricultural watershed. J Environ Qual 26(4):1038-1048

Davidson EA, David MB, Galloway JN, Goodale CL, Haeuber R, Harrison JA, Howarth RW, Jaynes DB, Lowrance RR, Nolan BT, Peel JL, Pinder RW, Porter E, Snyder CS, Townsend AR, Ward MH (2011) Excess nitrogen in the U.S. environment: trends, risks, and solutions. Issues Ecol 15:2-16

Davis JH, Griffith SM, Horwath WR, Steiner JJ, Myrold DD (2006) Fate of nitrogen-15 in a perennial ryegrass seed field and herbaceous riparian area. Soil Sci Soc Am J 70(3):909-919

Davis JH, Griffith SM, Horwath WR, Steiner JJ, Myrold DD (2008) Denitrification and nitrate consumption in an herbaceous riparian area and perennial ryegrass seed cropping system. Soil Sci Soc Am J 72(5):1299-1310

De Paz JM, Delgado JA, Ramos C, Shaffer MJ, Barbarick KK (2009) Use of a new GIS nitrogen index assessment tool for evaluation of nitrate leaching across a Mediterranean region. J Hydrol 365(3-4):183-194

Erway MM., Baxter K, Motter K, Echols S, Rodecap K (2005) Quality assurance plan: Willamette Research Station analytical laboratory. Dynamac Corporation, Corvallis Oregon. Revision 3, May 2005

Evans DM (2007) Dissolved Nitrogen in Surface Waters and Nitrogen Mineralization in Riparian Soils within a MultiLand Use Basin. Master thesis, Oregon State University

Ferguson RB (2015) Groundwater quality and nitrogen use efficiency in Nebraska's Central Platte River Valley. J Environ Qual 44(2):449-459

Fernández FG, Venterea RT, Fabrizzi KP (2016) Corn nitrogen management influencesnNitrous oxide emissions in drained and undrained soils. J Environ Qual 45(6):18471855
Galloway JN, Dentener FJ, Capone DG, Boyer EW, Howarth RW, Seitzinger SP, Asner GP, Cleveland CC, Green PA, Holland EA, Karl DM, Michaels AF, Porter JH, Townsend AR, Vöosmarty CJ (2004) Nitrogen cycles: past, present, and future. Biogeochemistry 70(2):153-226

Goolsby DA, Battaglin WA, Lawrence GB, Artz RS, Aulenbach BT, Hooper RP, Keeney DR, Stensland GJ (1999) Flux and sources of nutrients in the Mississippi-Atchafalaya River Basin: Topic 3 Report for the Integrated Assessment on Hypoxia in the Gulf of Mexico

Han H, Allan JD (2008) Estimation of nitrogen inputs to catchments: comparison of methods and consequences for riverine export prediction. Biogeochemistry 91(2-3):177199

Hirsch RM, Moyer DL, Archfield SA (2010) Weighted regressions on time, discharge, and season (WRTDS), with an application to Chesapeake Bay River Inputs1. JAWRA J Am Water Resour Assoc 46(5):857-880

Hoag D, Giannico G, Li J, Garcia T, Gerth W, Mellbye M, Mueller-Warrant G, Griffith S, Osmond D, Jennings G (2012) Calapooia Watershed, Oregon: National Institute of Food and Agriculture-Conservation Effects Assessment Project. How to Build Better Agricultural Conservation Programs to Protect Water Quality: The National Institute of Food and Agriculture-Conservation Effects Assessment Project Experience, p 387

Hoppe BO, Harding AK, Staab J, Counter M (2011) Private well testing in Oregon from real estate transactions: an innovative approach toward a state-based surveillance system. Public Health Rep 126(1):107

Howarth RW, Billen G, Swaney D, Townsend A, Jaworski N, Lajtha K, Downing JA, Elmgren R, Caraco N, Jordan T, Berendse F, Freney J, Kudeyarov V, Murdoch P, Zhu ZL (1996) Regional nitrogen budgets and riverine N \& P fluxes for the drainages to the North Atlantic Ocean: natural and human influences. Biogeochemistry 35(1):75-139

Howarth R, Swaney D, Billen G, Garnier J, Hong B, Humborg C, Johnes P, Mörth C-M, Marino R (2012) Nitrogen fluxes from the landscape are controlled by net anthropogenic nitrogen inputs and by climate. Front Ecol Environ 10(1):37-43

Keeney DR, DeLuca T (1993) Des Moines River nitrate in relation to watershed agricultural practices: 1945 versus 1980s. J Environ Qual 22(2):267-272

Kelley CJ, Keller CK, Evans RD, Orr CH, Smith JL, Harlow BA (2013) Nitrate-nitrogen and oxygen isotope ratios for identification of nitrate sources and dominant nitrogen cycle processes in a tile-drained dryland agricultural field. Soil Biol Biochem 57:731-738

Lacey C, Armstrong S (2015) The efficacy of winter cover crops to stabilize soil inorganic nitrogen after fall-applied anhydrous ammonia. J Environ Qual 44(2):442-448

Luscz EC, Kendall AD, Hyndman DW (2015) High resolution spatially explicit nutrient source models for the Lower Peninsula of Michigan. J Great Lakes Res 41(2):618-629

McIsaac GF, David MB, Gertner GZ, Goolsby DA (2002) Relating net nitrogen input in the Mississippi River Basin to nitrate flux in the Lower Mississippi River. J Environ Qual 31(5):1610-1622

Mueller-Warrant GW, Whittaker GW, Griffith SM, Banowetz GM, Dugger BD, Garcia TS, Giannico G, Boyer KL, 
McComb BC (2011) Remote sensing classification of grass seed cropping practices in western Oregon. Int J Remote Sens 32(9):2451-2480

Mueller-Warrant GW, Griffith SM, Whittaker GW, Banowetz GM, Pfender WF, Garcia TS, Giannico GR (2012) Impact of land use patterns and agricultural practices on water quality in the Calapooia River Basin of western Oregon. J Soil Water Conserv 67(3):183-201

Nolan BT, Hitt KJ (2006) Vulnerability of shallow groundwater and drinking-water wells to nitrate in the United States. Environ Sci Technol 40(24):7834-7840

Ohmann JL, Gregory MJ, Henderson EB, Roberts HM (2011) Mapping gradients of community composition with nearest-neighbour imputation: extending plot data for landscape analysis. J Veg Sci 22(4):660-676

Osmond DL, Hoag DLK, Luloff AE, Meals DW, Neas K (2014) Farmers' use of nutrient management: lessons from watershed case studies. J Environ Qual 44:382-390

Patil S, Stieglitz M (2014) Modelling daily streamflow at ungauged catchments: what information is necessary? Hydrol Process 28(3):1159-1169

Pennino MJ, Compton JE, Leibowitz SG (2017) Trends in drinking water nitrate violations across the United States. Environ Sci Technol 51:13450-13460

Perakis SS, Compton JE, Hedin LO (2005) Nitrogen retention across a gradient of ${ }^{15} \mathrm{~N}$ additions to an unpolluted temperate forest soil in Chile. Ecology 86:96-105

Piccini C, Di Bene C, Farina R, Pennelli B, Napoli R (2016) Assessing nitrogen use efficiency and nitrogen loss in a forage-based system using a modeling approach. Agronomy 6(2):23

Quemada M, Baranski M, Nobel-de Lange MNJ, Vallejo A, Cooper JM (2013) Meta-analysis of strategies to control nitrate leaching in irrigated agricultural systems and their effects on crop yield. Agr Ecosyst Environ 174:1-10

Robertson GP, Vitousek PM (2009) Nitrogen in agriculture: balancing the cost of an essential resource. Annu Rev Environ Resour 34:97-125

Runkel RL, Crawford CG, Cohn TA (2004) Load Estimator (LOADEST): a FORTRAN program for estimating constituent loads in streams and rivers. Available via USGS. https://pubs.usgs.gov/tm/2005/tm4A5/pdf/508final.pdf. Cited 15 April 2017

Runyon J, Andrus C, Schwindt R (2004) Calapooia River watershed assessment. Calapooia Watershed Council: Brownsville, OR. http://www.calapooia.org/wp-content/ uploads/2009/01/Calapooia\%20Assessment\%202-24-04. pdf. Cited 15 April 2017

Schaefer SC, Alber M (2007) Temperature controls a latitudinal gradient in the proportion of watershed nitrogen exported to coastal ecosystems. Biogeochemistry 85(3):333-346

Schaefer SC, Hollibaugh JT, Alber M (2009) Watershed nitrogen input and riverine export on the west coast of the US. Biogeochemistry 93(3):219-233

Schwede DB, Lear GG (2014) A novel hybrid approach for estimating total deposition in the United States. Atmos Environ 92:207-220

Selker J, Rupp DE (2004) Groundwater and nitrogen management in Willamette Valley mint production. Extension Service, Oregon State University, Corvallis
Sigler WA, Ewing SA, Jone CA, Payn RA, Brookshire EJ, Klassen JK, Jackson-Smith D, Weissmann G (2018) Connections among soil, ground, and surface water chemistries characterize nitrogen loss from an agricultural landscape in the upper Missouri River basin. J Hydrol 556:247-261

Sinha E, Michalak AM (2016) Precipitation dominates interannual variability of riverine nitrogen loading across the continental United States. Environ Sci Technol 50:12874-12884

Sobota DJ, Harrison JA, Dahlgren RA (2009) Influences of climate, hydrology, and land use on input and export of nitrogen in California watersheds. Biogeochemistry 94(1):43-62

Sobota DJ, Johnson SL, Gregory SV, Ashkenas LR (2012) A stable isotope tracer study of the influences of adjacent land use and riparian condition on fates of nitrate in streams. Ecosystems 15(1):1-7

Sobota DJ, Compton JE, Harrison JA (2013) Reactive nitrogen inputs to US lands and waterways: how certain are we about sources and fluxes? Front Ecol Environ 11(2):82-90

Sobota DJ, Compton JE, McCrackin ML, Singh S (2015) Cost of reactive nitrogen release from human activities to the environment in the United States. Environ Res Lett 10(2):025006

Stoner NK (2011) Working in partnership with states to address phosphorus and nitrogen pollution through use of a framework for state nutrient reductions. US Environmental Protection Agency, Memorandum to regional administrators. https://www.epa.gov/sites/production/files/ documents/memo_nitrogen_framework.pdf

USDA National Resources Conservation Service (NRCS). 2017. Soil survey of Linn County. https://websoilsurvey. nrcs.usda.gov/app/ Accessed August 2018

USEPA Imparied Waters and TMDLs in Region 10. Available via USEPA. https://www.epa.gov/tmdl/impaired-watersand-tmdls-region-10\#search. Accessed 23 February 2018

USGS (2013) Revision to LOADEST. Online document for Load Estimator (LOADEST): A Program for Estimating Constituent Loads in Streams and Rivers. Available via USGS website. https://water.usgs.gov/software/loadest/ doc/loadest_update.pdf. Accessed 5 April 2017

van Grinsven HJ, Holland M, Jacobsen BH, Klimont Z, Sutton MA, Jaap Willems W (2013) Costs and benefits of nitrogen for Europe and implications for mitigation. Environ Sci Technol 47(8):3571-3579

Wigington PJ, Griffith SM, Field JA, Baham JE, Horwath WR, Owen J, Davis JH, Rain SC, Steiner JJ (2003) Nitrate removal effectiveness of a riparian buffer along a small agricultural stream in Western Oregon. J Environ Qual 32:162-170

Wigington PJ, Moser TJ, Lindeman DR (2005) Stream network expansion: a riparian water quality factor. Hydrol Process 19(8):1715-1721

Wise DR, Johnson HM (2011) Surface-water nutrient conditions and sources in the United States Pacific Northwest. J Am Water Resour Assoc 47(5):1110-1135

Wise DR, Johnson HM (2013) Application of the SPARROW model to assess surface-water nutrient conditions and sources in the United States Pacific Northwest. US Geological Survey Scientific Investigations Report 2013-5103. 
Available via USGS. https://pubs.usgs.gov/sir/2013/5103/ pdf/sir20135103.pdf. Accessed 5 April 2017

Tesoriero AJ, Spruill TB, Mew HE Jr, Farrell KM, Harden SL (2005) Nitrogen transport andtransformations in a coastal plain watershed: Influence of geomorphology on flow paths and residence times. Water Resour Res. https://doi.org/10. 1029/2003WR002953

Young W, Youngberg H, Chilcote D, Hart J (1997) Spring nitrogen fertilization of perennial ryegrass seed crop. J Prod Agric 10(2):327-330
Zhang X, Davidson EA, Mauzerall DL, Searchinger TD, Dumas P, Shen Y (2015) Managing nitrogen for sustainable development. Nature 528(7580):51-59

Publisher's Note Springer Nature remains neutral with regard to jurisdictional claims in published maps and institutional affiliations. 


\section{Supplemental Information}

Seasonality of nitrogen balances in a Mediterranean climate watershed, Oregon, US

Jiajia Lin, Jana E. Compton, Scott G. Leibowitz, George Mueller-Warrant, William Matthews, Stephen H. Schoenholtz, Daniel M. Evans and Rob A. Coulombe. 
Seven sources of $\mathrm{N}$ included in the analysis were land application of agricultural fertilizer and manure from Concentrated Animal Feeding Operations (CAFOs), atmospheric deposition, biological $\mathrm{N}$ fixation (BNF) by crops, BNF associated with red alder trees (Alnus rubra) trees, non-agricultural fertilizer applied to developed lands, and non-sewered septic waste. ArcGIS layers of dominant $\mathrm{N}$ sources were clipped to the watershed and subwatershed boundaries, and utilized to quantify contributions of various $\mathrm{N}$ sources in the study area. We also estimated $\mathrm{N}$ input from point sources such as waste water treatment plants using US Geological Survey (USGS) SPARROW (SPAtially-Referenced Regression On Watershed Attributes) model results (Wise \& Johnson 2013), which accounted for $<0.05 \%$ of the $\mathrm{N}$ contribution to the CRW. Therefore, point sources were not included in our analysis.

\section{1. $\mathrm{N}$ input: data sources and methods}

\section{Agricultural fertilizer input}

State or county level fertilizer sales data are often used to estimate fertilizer input (Howarth et al. 2012; Wise \& Johnson 2011). These approaches take the fertilizer sales data and apply it at a constant areal rate to all National Land Cover Dataset (NLCD) cultivated cropland in the county. The outcome of this approach is that all cropland in the county has the same areal fertilizer input rate, which does not reflect the variation in $\mathrm{N}$ fertilizer use by crop type. We considered the county sales data to be too coarse and uniform for our study given the relatively small size of CRW. In order to generate an estimate of local input from synthetic fertilizer application that varies by crop type, we assigned the fertilizer application rate to each crop based on extension recommendations from Oregon State University (Table 1); these rates were further refined by discussions with university extension staff. We use the high rates of application based on strong regional agreement between the high rates and fertilizer sales data for 2008 (Compton et al., In 
prep.). The crop distribution and area was based on an Agricultural Research Service (ARS) land use data of the CRW, which was mapped at field level via vehicle survey. The fertilizer input for each crop was thus calculated as the product of the area of this plant and its fertilizer application rate. The total fertilizer input of the watershed was the sum of fertilizer inputs to the landscape associated with those crops within the watershed, as shown in Eq.1:

$N_{f r t, i n}=\sum_{i=1}^{i} A_{i} \times R_{i}$

\section{Eq. 1}

where $\boldsymbol{N}_{\boldsymbol{f r t}, \boldsymbol{i}}$ is the total input of fertilizer $\left(\mathrm{kg} \mathrm{N} \mathrm{ha}^{-1} \mathrm{yr}^{-1}\right)$ of the watershed; $\boldsymbol{A}_{\boldsymbol{i}}$ and $\boldsymbol{R}_{\boldsymbol{i}}$ are respectively the planting area (ha) and fertilizer application rate $\left(\mathrm{kg} \mathrm{N} \mathrm{ha}^{-1} \mathrm{yr}^{-1}\right)$ of crop $\boldsymbol{i}$.

\section{Atmospheric deposition}

The Community Multiscale Air Quality (CMAQ; Schwede \& Lear 2014) model output for 2008 at a $4 \mathrm{~km}$ grid resolution was applied to the watershed boundary for the estimation of TN deposition. The CMAQ model run was conducted at the National Exposure Research Laboratory at EPA. The model simulated deposition rates for both wet and dry deposition, oxidized and reduced forms of $\mathrm{N}$. The dry deposition was modeled and adjusted for bias based on measured data from monitoring networks, such as the Clean Air Status and Trends Network, the National Atmospheric Deposition Program (NADP), Ammonia Monitoring Network, and the Southeastern Aerosol Research and Characterization network. It was then combined with wet deposition values interpolated from measurements at the NADP National Trends Network to estimate rates of total $\mathrm{N}$ deposition (Schwede \& Lear 2014).

\section{Red alder BNF}

Red alder (Alnus rubra) N-fixation is an important natural N source in PNW streams (Compton et al. 2003; Wise \& Johnson 2011). A literature review indicated that most rates of alder fixation 
fell within the range of $100-200 \mathrm{~kg} \mathrm{~N} \mathrm{ha}^{-1} \mathrm{yr}^{-1}$ (Binkley et al. 1994). We applied a conservative estimate of $100 \mathrm{~kg} \mathrm{ha}^{-1} \mathrm{yr}^{-1}$ for $100 \%$ alder coverage in our computation. Red alder basal area as a proportion of all tree basal area was derived from the Landscape Ecology, Modeling, Mapping and Analysis (LEMMA; Ohmann et al. 2011) effort at Oregon State University (OSU).

LEMMA uses a generalized nearest-neighbor model to combines satellite data and ground truthed Forest Inventory and Analysis field plot data to map species cover and forest properties across Oregon and Washington (Ohmann et al. 2011). The spatially explicit rate of alder N fixation was then calculated by multiplying the annual fixation rate by the fraction of basal area occupied by red alder trees in a given $30 \times 30 \mathrm{~m}$ pixel (Eq. 2):

$N_{\text {alder, }, \text { in }}=\frac{B A_{\text {alder }}}{B A_{\text {all }}} \times 100 \mathrm{~kg} \mathrm{~N} \mathrm{ha}^{-1} \mathrm{yr}^{-1} \quad \mathrm{Eq} .2$

where $B A_{\text {alder }}$ stands for the basal area (ha) of red alder trees, and $B A_{\text {all }}$ is the basal area of all trees in the watershed.

\section{Agricultural BNF}

Agricultural BNF was calculated by multiplying $\mathrm{N}$ fixation rates by the area of associated crops. The crop types we considered for agricultural BNF in the CRW were alfalfa $\left(224 \mathrm{~kg} \mathrm{~N} \mathrm{ha}^{-1} \mathrm{yr}^{-1}\right)$, clover $\left(117 \mathrm{~kg} \mathrm{~N} \mathrm{ha}^{-1} \mathrm{yr}^{-1}\right)$, and grassland/pasture $\left(1 \mathrm{~kg} \mathrm{~N} \mathrm{ha}^{-1} \mathrm{yr}^{-1}\right)$; fixation rates were obtained from a 2011 EPA Science Advisory Board report (SAB 2011). Crop area of N fixers was derived from the 2008 ARS land use map of the CRW.

\section{CAFO manure}

The $\mathrm{N}$ input was calculated for each CAFO site in the CRW. All related data was acquired from the annual inspection record from the Oregon Department of Agriculture CAFO Program. The state program keeps records of field map, site land use, animal type and population, days on the 
farm (confined or grazing), estimated manure $\mathrm{N}$ loading loss, and application of fertilizer and manure at each site. Using these records, we were able to reconstruct $2008 \mathrm{~N}$ manure application for the ten CAFO sites occurring in the watershed. This approach works well with a small watershed with a small number of CAFO sites, improving spatial accuracy of the results without excessive workload for record retrieval and computation. CAFO data are not mapped in this paper due to privacy and confidential business concerns.

\section{Non-agricultural fertilizer}

We applied the USGS-SPARROW estimates of $\mathrm{N}$ input from non-agricultural fertilizer and nonsewered population (Wise \& Johnson 2013). The estimation of county-level non-agricultural fertilizer was based on statewide fertilizer sale and county-level expenditures, which was then disaggregated equally to the NLCD developed land (categories 21, 22, 23, and 24 minus areas representing roads) in each county (Wise \& Johnson 2013).

\section{Non-sewered septic waste}

The non-sewered $\mathrm{N}$ source represented the $\mathrm{N}$ leaching from septic tanks, which was also estimated based on the 2002 SPARROW model work. Population based on the 2000 U.S. census was distributed equally on the NLCD developed land. Grids that were served by municipal sewers were removed from calculation. An average annual per capita $\mathrm{N}$ leaching rate $(1.17 \mathrm{~kg} \mathrm{~N}$ person $^{-1} \mathrm{yr}^{-1}$, Wise and Johnson 2013) was assigned to the population to calculate $\mathrm{N}$ input from this source. The detailed computational method of the non-sewered population is described in the SPARROW document (Wise and Johnson 2013). 


\section{2. $\mathbf{N}$ export in streams}

LOADEST model was developed by USGS to estimate constituent loads in streams and rivers, based on statistical estimation methods (Runkel et al. 2004), and has been widely used to calculate $\mathrm{N}$ and phosphorus loads in riverine nutrient studies (Aulenbach \& Hooper 2006; Goolsby et al. 2000; Sobota et al. 2011; Zhang et al. 2015a). The LOADEST model requires input of stream nitrogen concentration and daily discharge data to simulate load at a daily basis. The methods of concentration measurement and discharge simulation are described as follows:

\section{Concentration measurement}

Intermittent surface water samples were collected from 15 mainstream and 58 tributary stations in the Calapooia River Watershed from 2003-2006 by USDA-ARS and OSU (monthly or quarterly), and from 2009-2011 by the Environmental Protection Agency (EPA) (quarterly). Samples were stored at $4{ }^{\circ} \mathrm{C}$ and filtered to 0.45 micron (USDA/OSU) or 0.4 micron (EPA), and analyzed within 48 hours (Floyd et al., 2009). Water samples were frozen at $-20{ }^{\circ} \mathrm{C}$ if analyzed after $48 \mathrm{~h}$. Total nitrogen (TN) and Total dissolved nitrogen (TDN) sampled by USDA and OSU were analyzed using a PC-Controlled Total Organic Carbon Analyzer using the catalytic thermal decomposition and chemi-luminescence method (Evans 2007; Evans et al. 2014). Total dissolved $\mathrm{N}$ concentration was also measured by EPA using alkaline persulfate digestion followed by conversion of nitrate to nitrite by cadmium reduction and colorimetric determination of nitrite using EDTA and sulfanilamide (Lachat method 10-107-04-1-C; Erway et al. 2005). The detection limit for the Lachat TDN method is $0.010 \mathrm{mg} \mathrm{N} \mathrm{L}^{-1}$; the detection limit for the USDA-ARS method is $0.04 \mathrm{mg} \mathrm{N} \mathrm{L}^{-1}$. The two methods produce comparable results (Sharp et al. 2004), and the difference in detection limit only affects $5 \%$ of the samples. 


\section{Discharge simulation}

For the CRW, a hybrid hydrologic model combines a physically-based, rainfall-runoff model, EXP-HYDRO (Patil \& Stieglitz 2014), to represent lowland discharge in the lower Calapooia, and an indexed regression model to represent mountain discharge in the upper Calapooia. EXPHYDRO uses local precipitation and temperature data to simulate stream discharge of the lower flat land. Since suitable climate data were not available for the mountainous area, a regression model was constructed to simulate mountain discharge that was driven by runoff from two index mountain streams outside the Calapooia River Watershed: Mohawk River and Wiley Creek. The simulated discharge at each site was then calculated as an area-weighted sum of the lowland discharge and mountain discharge.

The model was calibrated at one tributary site using s discharge-pressure transducer rating curve developed by USGS to create hourly discharge estimates. Validation of the calibrated model was then carried out at 20 other subwatersheds with periodic flow measurements, which generated satisfactory results. The Nash-Sutcliffe coefficient $\left(\mathrm{R}_{\mathrm{NS}}{ }^{2}\right)$ used to compare observed and estimated daily discharge for each subwatershed was found ranging from 0.23 to 0.97 and averaging 0.73 . $\mathrm{R}_{\mathrm{NS}}^{2}$ values were greater than 0.6 for all but two of the subwatersheds.

The LOADEST simulation produced continuous TN load output at a daily step, which was then aggregated to calculate monthly, seasonal, and annual stream export of TN at the Calapooia River main stem and tributary sites. The simulation at each site was evaluated and calibrated using the Nash-Sutcliffe coefficient $\left(\mathrm{R}_{\mathrm{NS}}{ }^{2}\right)$ and Load Bias in Percent $\left(\mathrm{B}_{\mathrm{P}}\right)$, a coefficient that describes percent over/under estimation of the observed load within the calibration data set (USGS, 2013). The $\mathrm{R}_{\mathrm{Ns}}{ }^{2}$ ranged between 0.60 to 0.97 among all but five subwatersheds, and averaged 0.77 for all sites. The calibrated absolute value of $B_{p}$ averaged $6.4 \%$ for all 
subwatersheds and ranged from 0 to $10.7 \%$ for 63 subwatersheds, and from $12.3 \%$ to $24.4 \%$ for the remaining 10 subwatersheds. 
Table S1. Range of nitrogen fertilizer application rate (lb N/ha) for land uses in the Calapooia River Watershed, Oregon, USA.

\begin{tabular}{|c|c|c|c|}
\hline Land use & $\begin{array}{l}\text { Low } \\
\text { rate }\end{array}$ & $\begin{array}{l}\text { High } \\
\text { rate }\end{array}$ & Reference \\
\hline Bare ground in fall (not otherwise classed) & 20 & 40 & Personal communication \\
\hline Full straw Italian ryegrass (annual ryegrass) & 120 & 160 & Mellbye et al., 2003 \\
\hline Spring planting new grass seed stand & 20 & 40 & Personal communication \\
\hline Established perennial ryegrass & 150 & 200 & Hart et al., 2005a \\
\hline Established orchardgrass & 110 & 140 & Doerge et al., 2000 \\
\hline Established tall fescue & 120 & 180 & Hart et al., 2005b \\
\hline Pasture & 100 & 120 & Pirelli et al., 2004 \\
\hline Established clover & 0 & 0 & Gardner et al., 2000a\&c \\
\hline Established mint & 200 & 250 & Hart et al., 2010 \\
\hline Haycrop & 40 & 90 & Personal communication \\
\hline Poplars & 0 & 0 & Personal communication \\
\hline Fall plant Italian ryegrass & 120 & 160 & Mellbye et al., 2003 \\
\hline Fall plant perennial ryegrass & 150 & 200 & Hart et al., 2005a \\
\hline Fall plant tall fescue & 120 & 180 & Hart et al., 2005b \\
\hline Fall plant clover & 0 & 0 & Personal communication \\
\hline Wheat or other cereals & 100 & 230 & Hart et al., 2009a \\
\hline Meadowfoam & 40 & 60 & Personal communication \\
\hline Established bentgrass & 100 & 130 & Gardner et al., 1999 \\
\hline Established fine fescue & 45 & 90 & Gingrich et al., 2003 \\
\hline Christmas trees & 0 & 150 & Hart et al., 2009b \\
\hline Wildrice & 0 & 0 & \\
\hline Wetlands restoration & 0 & 0 & \\
\hline Established alfalfa & 0 & 0 & Gardner et al., 2000b \\
\hline Established blueberries & 100 & 165 & Hart et al., 2006b \\
\hline Filberts (Hazelnuts) & 99 & 115 & Olsen 2001 \\
\hline Caneberry & 50 & 70 & Hart et al., 2006a \\
\hline Corn & 40 & 215 & Hart et al., 2009c \\
\hline Nursery crops & 0 & 0 & \\
\hline Orchard crops (apple, cherry) & 15 & 50 & Righetti et al., 1998 \\
\hline Fallow & 0 & 0 & \\
\hline Urban development & 0 & 0 & \\
\hline Vineyard & 0 & 6 & Personal communication \\
\hline Reforestation & 0 & 0 & \\
\hline Established trees other than poplars & 0 & 0 & \\
\hline Beans - summer annual cropping & 50 & 80 & Mansour et al., 2000 \\
\hline Flowers, assorted & 0 & 0 & \\
\hline
\end{tabular}




\begin{tabular}{|c|c|c|c|}
\hline Oak trees & 0 & 0 & \\
\hline Established hops & 100 & 150 & Gingrich et al., 2000 \\
\hline Shrubs, wildlife refuge & 0 & 0 & \\
\hline NT fall plant $\mathrm{OG}$ and NT TF, HR, $\mathrm{CL}^{1}$ & 20 & 20 & Personal communication \\
\hline $\begin{array}{l}\text { Spring planting unidentified grass seed, peas, } \\
\text { mint }\end{array}$ & 0 & 0 & \\
\hline New planting poplars, blueberries, hops & 0 & 0 & \\
\hline Alfalfa new planting & 0 & 0 & \\
\hline Volunteer Italian ryegrass grazed as pasture & 0 & 0 & \\
\hline $\mathrm{NLCD}^{2} 90$ open water & 0 & 0 & \\
\hline NLCD $^{2} 90$ woody wetlands & 0 & 0 & \\
\hline $\mathrm{NLCD}^{2} 95$ herbaceous wetlands & 0 & 0 & \\
\hline $\mathrm{NLCD}^{2} 21$ developed open space & 0 & 0 & \\
\hline $\mathrm{NLCD}^{2} 22$ developed low intensity & 0 & 0 & \\
\hline $\mathrm{NLCD}^{2} 23$ developed medium intensity & 0 & 0 & \\
\hline $\mathrm{NLCD}^{2} 41$ deciduous forest & 0 & 0 & \\
\hline $\mathrm{NLCD}^{2} 43$ evergreen forest & 0 & 0 & \\
\hline $\mathrm{NLCD}^{2} 44$ mixed forest & 0 & 0 & \\
\hline $\mathrm{NLCD}^{2} 53 \mathrm{scrub} / \mathrm{shrub}$ & 0 & 0 & \\
\hline Radish, brassicas & 50 & 75 & Personal communication \\
\hline Strawberries & 25 & 50 & Hart et al., 2000 \\
\hline $\mathrm{NLCD}^{2} 24$ developed high intensity & 0 & 0 & \\
\hline
\end{tabular}

${ }^{1} \mathrm{NT}$ : no till; OG: orchardgrass; TF: tall fescue; HR: hybrid ryegrass; CL: clover

${ }^{2}$ NLCD: National Land Cover Dataset

\section{References}

Aulenbach BT, Hooper RP (2006) The composite method: an improved method for stream-water solute load estimation. Hydrological Processes 20(14): 3029-3047

Binkley D, Cromack Jr K, Baker D (1994) Nitrogen fixation by red alder: biology, rates, and controls. The biology and management of red alder. Oregon State University Press, Corvallis: $57-72$ 
Compton JE, Church MR, Larned ST, Hogsett WE (2003) Nitrogen export from forested watersheds in the Oregon Coast Range: the role of N2-fixing red alder. Ecosystems 6(8): 773-785

Compton JE, Goodwin KE, Sobota DJ, Lin J (In preparation) Sources and seasonality of nitrogen input and hydrologic export within the Willamette River Basin, Oregon

Doerge T, Gardner H, Jackson TL, Youngberg H (2000) Fertilizer guide for orchardgrass seed, Western Oregon-west of Cascades. Available via Oregon State University Extension Service. https://catalog.extension.oregonstate.edu/topic/agriculture/fertilizer-guides. Cited 13 October 2017

Erway MM., Baxter K, Motter K, Echols S, Rodecap K (2005) Quality Assurance Plan: Willamette Research Station Analytical Laboratory. Dynamac Corporation, Corvallis Oregon. Revision 3, May 2005

Evans DM (2007) Dissolved Nitrogen in Surface Waters and Nitrogen Mineralization in Riparian Soils within a Multi-Land Use Basin. Master thesis, Oregon State University

Evans DM, Schoenholtz SH, Wigington Jr PJ, Griffith SM, Floyd WC (2014) Spatial and temporal patterns of dissolved nitrogen and phosphorus in surface waters of a multi-land use basin. Environmental Monitoring and Assessment 186(2): 873-887

Floyd WC, Schoenholtz SH, Griffith SM, Wigington PJ, Jr., Steiner JJ (2009) Nitrate-nitrogen, land use/land cover, and soil drainage associations at multiple spatial scales. Journal of environmental quality 38(4): 1473-1482 
Gardner EH, Doerge TA, Hannaway DB, Youngberg H, McGuire WS (2000a) Fertilizer guide for crimson clover, vetch, field peas, Western Oregon-west of Cascades. Available via Oregon State University Extension Service. https://catalog.extension.oregonstate.edu/topic/agriculture/fertilizer-guides. Cited 13 October 2017

Gardner EH, Hannaway DB, Jackson TL, McGuire WS (2000b) Fertilizer guide for alfalfa, Willamette Valley and Northwest Oregon. Available via Oregon State University Extension Service. https://catalog.extension.oregonstate.edu/topic/agriculture/fertilizerguides. Cited 13 October 2017

Gardner EH, Jackson TL, Doerge TA, Hannaway DB, McGuire WS (2000c) Fertilizer guide for red clover, Western Oregon-west of Cascades. Available via Oregon State University Extension Service. https://catalog.extension.oregonstate.edu/topic/agriculture/fertilizerguides. Cited 13 October 2017

Gardner EH, Jackson TL, Youngberg H (1999) Fertilizer guide for bentgrass seed, Western Oregon-west of Cascades. Available via Oregon State University Extension Service. https://catalog.extension.oregonstate.edu/topic/agriculture/fertilizer-guides. Cited 13 October 2017

Gingrich C, Hart J, Christensen N (2000) Fertilizer guide for hops. Available via Oregon State University Extension Service. https://catalog.extension.oregonstate.edu/topic/agriculture/fertilizer-guides. Cited 13 October 2017 
Gingrich GA, Hart JM, Horneck DA, Young III WC, Silberstein TB (2003) Fertilizer guide for fine fescue seed (Western Oregon). Available via Oregon State University Extension Service. https://catalog.extension.oregonstate.edu/topic/agriculture/fertilizer-guides. Cited 13 October 2017Goolsby DA, Battaglin WA, Aulenbach BT, Hooper RP (2000) Nitrogen flux and sources in the Mississippi River Basin. Science of the Total Environment 248(2): 75-86

Hart JM, Flowers MD, Roseberg RJ, Christensen NW, Mellbye ME (2009a) Nutrient management guide for soft white winter wheat (Western Oregon). Available via Oregon State University Extension Service. https://catalog.extension.oregonstate.edu/topic/agriculture/fertilizer-guides. Cited 13 October 2017

Hart JM, Langren C, Fletcher R, Bondi M, Withrow-Robinson B, Chastagner G (2009b). Christmas tree utrient management guide, Western Oregon and Washington. Available via Oregon State University Extension Service. https://catalog.extension.oregonstate.edu/topic/agriculture/fertilizer-guides. Cited 13 October 2017

Hart JM, Mellbye ME, Horneck DA, Gingrich GA, Young III WC, Silberstein TB (2005a) Fertilizer guide for perennial ryegrass grown for seed (Western Oregon). Available via Oregon State University Extension Service. https://catalog.extension.oregonstate.edu/topic/agriculture/fertilizer-guides. Cited 13 October 2017 
Hart JM, Mellbye ME, Horneck DA, Gingrich GA, Young III WC, Silberstein TB (2005b)

Fertilizer guide for tall fescue grown for seed (Western Oregon). Available via Oregon State University Extension Service.

https://catalog.extension.oregonstate.edu/topic/agriculture/fertilizer-guides. Cited 13

October 2017

Hart JM, Righetti TL, Sheets A, Martin LW (2000) Fertilizer guide for strawberries, Western Oregon-west of Cascades. Available via Oregon State University Extension Service. https://catalog.extension.oregonstate.edu/topic/agriculture/fertilizer-guides. Cited 13

October 2017

Hart JM, Strik B, Rempel H (2006) Nutrient management guide for caneberries. Available via Oregon State University Extension Service. https://catalog.extension.oregonstate.edu/topic/agriculture/fertilizer-guides. Cited 13 October 2017

Hart JM, Strik B, White L, Yang W (2006) Nutrient management for blueberries in Oregon. Available via Oregon State University Extension Service. https://catalog.extension.oregonstate.edu/topic/agriculture/fertilizer-guides. Cited 13 October 2017

Hart J, Sullivan D, Gamroth M, Downing T, Peters A (2009c) Nutrient management guide for silage corn (Western Oregon). Available via Oregon State University Extension Service. https://catalog.extension.oregonstate.edu/topic/agriculture/fertilizer-guides. Cited 13 October 2017Hart JM, Sullivan DM, Mellbye ME, Hulting AG, Christensen NW, Gingrich GA (2010) Nutrient management guide for peppermint (Western Oregon). 
Available via Oregon State University Extension Service.

https://catalog.extension.oregonstate.edu/topic/agriculture/fertilizer-guides. Cited 13

October 2017

Howarth R, Swaney D, Billen G, Garnier J, Hong B, Humborg C, Johnes P, Mörth C-M, Marino R (2012) Nitrogen fluxes from the landscape are controlled by net anthropogenic nitrogen inputs and by climate. Frontiers in Ecology and the Environment 10(1): 37-43

Mansour NS, Mack HJ, Gardner EH, Jackson TL (2000) Fertilizer guide for bush beans, Western Oregon-west of Cascades. Available via Oregon State University Extension Service. https://catalog.extension.oregonstate.edu/topic/agriculture/fertilizer-guides. Cited 13 October 2017

Mellbye ME, Hart JM, Horneck DA, Young III WC, Silberstein TB (2003) Fertilizer guide annual ryegrass (Western Oregon). Available via Oregon State University Extension Service. https://catalog.extension.oregonstate.edu/topic/agriculture/fertilizer-guides. Cited 13 October 2017

Ohmann JL, Gregory MJ, Henderson EB, Roberts HM (2011) Mapping gradients of community composition with nearest-neighbour imputation: Extending plot data for landscape analysis. Journal of Vegetation Science 22(4): 660-676

Olsen J (2001) Nutrient management guide for hazelnuts. Available via Oregon State University Extension Service. https://catalog.extension.oregonstate.edu/topic/agriculture/fertilizerguides. Cited 13 October 2017 
Patil S, Stieglitz M (2014) Modelling daily streamflow at ungauged catchments: what information is necessary? Hydrological Processes 28(3): 1159-1169Pirelli G, Hart J, Filley S, Peters A, Porath M, Downing T, Bohle M, Carr J (2004) Early spring forage production for Western Oregon Pastures. Available via Oregon State University Extension Service. https://catalog.extension.oregonstate.edu/topic/agriculture/fertilizerguides. Cited 13 October 2017Patil S, Stieglitz M (2014) Modelling daily streamflow at ungauged catchments: what information is necessary? Hydrological Processes 28(3): 1159-1169

Righetti T, Wilder K, Stebbins R, Burkhart D, Hart J (1998) Nutrient management guide for apples. Available via Oregon State University Extension Service. https://catalog.extension.oregonstate.edu/topic/agriculture/fertilizer-guides. Cited 13 October 2017

SAB (2011) Reactive nitrogen in the United States: an analysis of inputs, flows, consequences, and management options. In. EPA-SAB-11-013. Washington, DC: Science Advisory Board, US Environmental Protection Agency (Aug 2011). Available: http://yosemite. epa.gov/sab/sabproduct.nsf/WebBOARD/INCSupplemental.

Schwede DB, Lear GG (2014) A novel hybrid approach for estimating total deposition in the United States. Atmospheric Environment 92: 207-220

Sharp J, Beauregard A, Burdige D, Cauwet G, Curless S, Lauck R, Nagel K, Ogawa H, Parker A, Primm O (2004) A direct instrument comparison for measurement of total dissolved nitrogen in seawater. Marine Chemistry 84(3): 181-193 
Sobota DJ, Harrison JA, Dahlgren RA (2011) Linking dissolved and particulate phosphorus export in rivers draining California's Central Valley with anthropogenic sources at the regional scale. Journal of environmental quality 40(4): 1290-1302

USGS (2013) Revision to LOADEST. Online document for Load Estimator (LOADEST): A Program for Estimating Constituent Loads in Streams and Rivers. Available via USGS website. https://water.usgs.gov/software/loadest/doc/loadest update.pdf. Cited 5 April 2017

Wise DR, Johnson HM (2011) Surface-Water Nutrient Conditions and Sources in the United States Pacific Northwest. Journal of the American Water Resources Association 47(5): $1110-1135$

Wise DR, Johnson HM (2013) Application of the SPARROW model to assess surface-water nutrient conditions and sources in the United States Pacific Northwest. US Geological Survey Scientific Investigations Report 2013-5103. Available via USGS. https://pubs.usgs.gov/sir/2013/5103/pdf/sir20135103.pdf. Cited 5 April 2017 